\title{
Who Measures the Chancellor's Foot? The Inherent Remedial Authority of the Federal Courts $\dagger$
}

\author{
John Choon Yooł
}

\section{INTRODUCTION}

In Missouri v. Jenkins (Jenkins III), ${ }^{1}$ the Supreme Court began a reexamination of the inherent remedial authority of the federal courts. This doctrinal development should be of great interest to a symposium on race-based remedies because, since the days of Brown v. Board of Education (Brown II), ${ }^{2}$ the federal courts have used their remedial powers to desegregate the schools ${ }^{3}$ and to order affirmative action

Copyright $\odot 1996$ California Law Review, Inc.

$\dagger$ Commenting on the discretion available to judges of the courts of equity, John Selden said:

Equity is A Roguish thing, for Law wee have a measure know what to trust too. Equity is according to $y^{e}$ conscience of him $y^{t}$ is Chancellor, and as $y^{t}$ is larger or narrower soe is equity Tis all one as if they should make ye Standard for $\mathrm{y}^{\mathrm{e}}$ measure wee call $\mathrm{A}$ foot, to be $y^{e}$ Chancellors foot; what an uncertain measure would this be; One Chancellor ha's a long foot another A short foot a third an indifferent foot; tis $y^{e}$ same thing in $y^{e}$ Chancellors Conscience.

John SELden, Table TalK of John Selden 43 (Frederick Pollock ed., 1927) (footnotes omitted).

$¥ \quad$ Acting Professor of Law, University of California at Berkeley (Boalt Hall); J.D., 1992, Yale Law School; A.B., 1989, Harvard College. I would like to thank Jesse Choper, Bill Eskridge, Paul Mishkin, and Robert Post for providing generous comments on the manuscript. 1 also would like to thank Jasen Adams, Akhil Amar, Larry Block, Steve Calabresi, Manus Cooney, Ann Coulter, Susan Davies, Viet Dinh, Mark Disler, John Dwyer, Ed Gaffney, Jack Goldsmith, Eric Grant, Stephen Higgins, Mike Hirshland, Sheila John, Michael Kennedy, Chris Landau, Thomas Lee, Leonard Leo, Jeannette Lopatto, Kevin McGuiness, John McMickle, Caleb Nelson, Ted Olson, Michael O'Neill, Lee Otis, Saikrishna B. Prakash, Edward Richards, Melissa Riley, Dan Rodriguez, Howard Shelanski, Cornelius A. Vermeule, and Paul Zidlicky. Special mention goes to Amy Haddix and Joe Matal of the Boalt Hall Class of 1996 for inviting me to participate in this symposium. As always, I must thank Elsa Arnett and Chris Yoo for their unflagging support and encouragement.

1. $115 \mathrm{~S}$. Ct. 2038, 2051 (1995) (holding that a district court's desegregation orders exceeded its remedial authority).

2. 349 U.S. 294, 301 (1955) (ordering desegregation of public schools with "all deliberate speed"). Brown II itself implemented the earlier finding, in Brown v. Board of Education, 347 U.S. 483 (I954) (Brown I), that segregation was unconstitutioual.

3. See, e.g., Milliken v. Bradley, 433 U.S. 267, 288-90 (1977) (Milliken II) (holding that a desegregation remedy may include remedial or compensatory education programs paid for by the state); Swann v. Charlotte-Mecklenburg Bd. of Educ., 402 U.S. 1, 27-29 (197I) (holding that courts may reassign students to remedy past de jure segregation); United States v. Montgomery County Bd. of Educ., 395 U.S. 225, 232-34 (1969) (holding that desegregation may occur according to matheinatical ratios). 
remedies. ${ }^{4}$ Regardless of whether one believes that the federal government may use race-conscious measures to cure the effects of discrimination, ${ }^{5}$ an important question in the years ahead will be whether the federal courts possess the inherent authority to impose broad, structural remedies upon state institutions.

The answer to this question will have significant ramifications not only for race-based remedies, but for all "public law litigation."6 Pursuant to their inherent remedial powers, federal courts have taken control of a number of state institutions, including prisons, ${ }^{7}$ mental mstitutions, ${ }^{8}$ and public housing. 9 Through the nse of the "structural injunction," this control often has shown minimal regard for the limits of the federal courts' inherent powers. Indeed, until the last two Terms, the Supreme Court demonstrated meaningful concern for the lower courts' invocation of this authority on a sporadic basis, and rarely invalidated a remedial plan. The Snpreme Court even has gone so far as to approve district court orders raising local property taxes ${ }^{11}$ and imposing contempt citations and daily fines for failure to comply with judicially-mandated spending increases. ${ }^{12}$

Some legal academics have praised, while others have criticized, the federal courts' use of such broad remedial powers. Some commentators, such as Professors Abram Chayes and Owen Fiss, have applauded and encouraged the efforts of the lower federal courts to take control of several elements of state and local government. ${ }^{13}$ As Owen Fiss describes the purposes of the structural injunction: "The strnctural suit is one in which a judge, confronting a state bureaucracy over values of constitutional dimension, undertakes to restructure the organization to eliminate a threat to those values posed by the present institutional arrangements. The injunction is the means by which these reconstructive

4. See, e.g., Firefighters Local Union No. 1784 v. Stotts, 467 U.S. 561 (1984).

5. The Supreme Court answered this very question in Adarand Constructors, Inc. v. Pena, 115 S. Ct. 2097 (1995). The Court held that race-baced remedies must satisfy strict scrutiny: they must advance a compelling government interest and they must be narrowly tailored toward that end. Id. at 2112.

6. As the phrase is commonly used, public law litigation refers to broad class action suits against state govemments and institutions. The purpose of such suits is to bring about social progress and reform by vindicating statutory or constitutional rights. For a more detailed discussion of public law litigation, see Abram Chayes, The Role of the Judge in Public Law Litigation, 89 HARv. L. Rev. 1281 (1976); Owen M. Fiss, The Supreme Court, 1978 Term-Foreword: The Forms of Justice, 93 HARV. L. REv. 1 (1979).

7. See, e.g., Casey v. Lewis, 43 F.3d 1261 (9th Cir. 1994), rev'd, 1996 U.S. LEXIS 4220 (June 24, 1996); Hutto v. Finney, 437 U.S. 678 (1978).

8. See, e.g., Thomas S. v. Flaherty, 902 F.2d 250 (4th Cir), cert. denied, 498 U.S. 951 (1990).

9. See, e.g., Hills v. Gautreaux, 425 U.S. 284 (1976).

10. See, e.g., OWen M. Fiss, The Civil Rights InJunction 9-10 (1978).

11. See Missouri v. Jenkins, 495 U.S. 33, 55 (1990) (Jenkins II).

12. See Spallone v. United States, 493 U.S. 265 (1990).

13. See Chayes, supra note 6; Fiss, supra note 6. 
directives are transmitted."14 In this vision, federal courts are both the oracles of public values and the enforcers of these values on wayward state bureaucracies.

Other academics have criticized the new role that judges have played in structural reform, primarily on the ground that federal courts are imstitutionally and functionally ill-suited to the task of administering public institutions. ${ }^{15}$ Federal judges, these scholars observe, have little experience in managing large, bureaucratic institutions. Furthermore, these authors argue, the process of litigation does not necessarily provide a trusty mechanism for providing judges with reliable information and feedback. Finally, federal judges are unelected and unaccountable, and thus feel little sense of balance or responsibility when ordering the expenditure of state funds. ${ }^{16}$ As my colleague, Professor Paul Mishkin, has written, institutional decrees "involve the taking over of institutions of state or local government by federally-appointed lawyers neither chosen by nor responsive to an electorate, neither charged with nor even assuming responsibility for the ultimate directional thrust or effectiveness of the institutions of state or local government."

In this Article I hope to identify the fundamental problem with the judiciary's assertion of inherent remedial power. Not only does this power violate principles of judicial restraint, but it also oversteps the limitations on the power of the federal courts imposed by Article III. The legitimacy of federal judicial management of state institutions does not ultimately turn on whether federal courts are functionally wellsuited to the job-although such institutional difficulties are a symptom of the disease. Instead, the essential flaw of judicial management is that the Constitution does not permit the federal courts to exercise their remedial powers to engage im the structural reform of local institutions and local government. If the remedies needed to correct a constitutional violation lie outside a court's traditional remedial powers, then separation of powers principles require that the answer come from the

14. Fiss, supra note 6 , at 2 .

15. See, e.g., Raoul Berger, Government by Judiciary: The Transformation of the Fourteenth Amendment (1977); Lino A. Graglia, Disaster By Decree: The Supreme Court Decisions on Race and the Schools (1976); Donald L. Horowitz, The CourTs and Social Policy 249-98 (1977); Peter Schuck, Suing Government: Citizen Remedies for Official Wrongs 150-81 (1983); Lon L. Fuller, The Forms and Limits of Adjudication, 92 HARV. L. REv. 353, 393-405 (1978); Paul J. Mishkin, Federal Courts as State Reformers, 35 WASH. \& LEE L. REv. 949 (1978); Robert F. Nagel, Separation of Powers and the Scope of Federal Equitable Remedies, 30 STAN. L. REV. 661 (1978) (arguing that separation of powers limits the ability of the judiciary to undertake executive or legislative functions when ordering relief against federal officials).

16. For a balanced and critical approach to the legitimacy of such exercises of judicial powers, see William A. Fletcher, The Discretionary Constitution: Institutional Remedies and Judicial Legitimacy, 91 YALE L.J. 635 (1982).

17. Mishkin, supra note 15 , at 971 (citation omitted). 
political branches, which are far better equipped to manage the structural reform of state and local institutions.

I

The Rise of Judicial Management

\section{A. The Outlines of Structural Reform Litigation}

Today, many of the institutions of state government find themselves under the control of the federal courts. In 1994, federal court orders regulated the conditions of confinement in 244 prisons in thirtyfour different jurisdictions, and they set the level of the inmate population in twenty-four prisons. ${ }^{18}$ The Department of Education reports that hundreds of school districts remain under federal court order. ${ }^{19}$ Figures concerning other state institutions, such as public housing authorities, police and firefighting forces, and mental hospitals, are unavailable but are probably high as well, if anecdotal evidence is any guide. For example, in the District of Columbia (although not a state), court orders affect the operations of the Department of Corrections, the Fire Department, the Human Services Department (which includes foster care, welfare, mental health, and juvenile offender programs), the Education Department, the Public Works Departinent, and the Public Housing agency. ${ }^{20}$ The District of Columbia does not seem to be unusual in the breadth of the federal courts' management of its institutions. At one point in the 1970s, it appears that federal courts had taken control simultaneously of Alabama's schools, mental hospitals, and prisons. ${ }^{21}$

These judicial actions generally share common characteristics. They begin when a group brings a class action suit against state and local governments and institutions that alleges broad constitutional violations. Typically, there are hundreds, if not thousands, of affected plamtiffs, as well as numerous other parties, amici, and intervenors. Often, the claims span dozens of years and the proceedings on liability often require years of motions, testimony, and discovery to resolve.

18. Crmmal Justice Institute, InC., The Corrections Yearbook 1994, at 6 (1995), cited in Enhancing the Effectiveness of Incarceration: Hearing on Prison Reform Before the Senate Judiciary Committee, 104th Cong., 2d Sess. (1995) (statement of Senator Orrin G. Hatch). According to the American Civil Liberties Union, 39 states, the District of Columbia, Puerto Rico, and the Virgin Islands are under court order or consent decree to limit their prison populations and/or to improve prison conditions. American Civil Liberties Union, Status Report: State Prisons and the Courts (1995).

19. U.S. Department of Education (unpublished figures, on file with author).

20. U.S. General Accounting Office, D.C. Court Orders, Feb. 15, 1994, GAO/GGD-9475R.

21. See Mishkin, supra note 15 , at 950 \& n.6. 
Jenkins III ${ }^{22}$ is a perfect example of the breadth and scope of structural injunction cases. The named plaimtiffs, who were parents of childreu attending the Kansas City, Missouri, School District (KCMSD), alleged that the State of Missouri, the KCMSD, and the surrounding suburban school districts had caused and perpetuated a system of racial segregation, in violation of the Equal Protection Clause of the Fourteenth Amendment. ${ }^{23}$ After almost seveu years of litigation, the district court found that the State of Missouri and the KCMSD had failed in their affirmative duty to eliminate the "vestiges" of state-sponsored discrimination. ${ }^{24}$ As evidence of the state's failure to comply with the Constitution, the district court found that Missouri had mandated segregation until the Court's 1954 decision in Brown I, and that by 1977, many schools still remained more than ninety percent AfricanAmerican. ${ }^{25}$

In the typical structural reform case a finding of a constitutional violation is only the first step in a sprawling, seemingly endless process of using injunctive decrees to reform the defendant institution. Often, the judge will decide upon a remedial plan only after consulting with the plaintiffs, the state and institutional defendants, expert witnesses, community leaders, and sometimes its own appointed masters or special committees. ${ }^{26}$ New hearings and, consequently, new decrees, may occur at regular intervals to receive feedback on the progress of, and compliance with, the remedy, and to institute modifications to the underlying remedial plan.

For example, in Jenkins, the district court entered its first remedial decree in $1985,{ }^{27}$ and appears to be issuing further orders today. ${ }^{28}$ The district court appears to hold regular hearings to set the school district's budget and address other program issues. ${ }^{29}$ These proceedings require repeated guidance from the appellate courts, which often are called upon to review the many decisions of the district court. In the Jenkins

22. 115 S. Ct. 2038 (1995).

23. Id. at 2042.

24. Id.

25. Id.

26. See, e.g., Lewis v. Casey, 1996 U.S. LEXIS 4220, at *7 (June 24, 1996) (describing consultation process used by district court); Jenkins III, 115 S. Ct. at 2042-43; id. at 2072 n.6 (Thomas, J., concurring) (describing use of "desegregation monitoring committee").

27. Jenkins v. Missouri, 639 F. Supp. 19, 23 (W.D. Mo. 1985), aff'd, 807 F.2d 657 (8th Cir. 1986), cert. denied, 484 U.S. 816 (1987).

28. Jenkins III, $115 \mathrm{~S}$. Ct. at 2042. There are other cases in which the remedial proceedings have been going on for much longer. See, e.g., Board of Educ. v. Dowell, 498 U.S. 237, 240 (1991) ("This school desegregation litigation began almost 30 years ago.").

29. Jenkins III, $115 \mathrm{~S}$. Ct. at 2072 n.6 (Thomas, J., concurring) ("Every year the District Court holds a proceeding to review budget proposals and education policies."). 
litigation, the Supreme Court has heard the case three times and the court of appeals has visited the case more than twenty times. ${ }^{30}$

Process is not the only thing that expands when courts consider structural injunctions; the reach of a federal court's power grows as well. A federal court may conclude that the widespread nature of the constitutional violation justifies judicial intervention in the most basic policies and activities of the state or local government. ${ }^{31}$ The relief may differ drastically from the monetary damages or negative injunctions that courts customarily award. Instead, the remedial decree will take the form of affirmative injunctions that require the defendant to undertake certain conduct or meet specified goals. ${ }^{32}$ Courts will make decisions concerning the hiring of personnel, the allocation and spending of state funds, the impleinentation of operational and compensatory programs, and the construction of new facilities. ${ }^{33}$

In issuing these affirmative injunctions, the district courts render numerous decisions, both large and sinall, that traditionally have been within the province of state and local legislators and administrators. In the school context, the Supreme Court has approved remedial plans that desegregate faculty and staff according to strict mathematical ratios, ${ }^{34}$ order busing, set racial targets for students bodies and change attendance zones, ${ }^{35}$ and initiate remedial education programs. ${ }^{36}$ Both the broad scope and the minute detail of such judicial decisions are best exemplified by the remedial plan in the Jenkins litigation. As Justice Kennedy put it, the district court's massive expenditures had financed

high schools in which every classroom will have air conditioning, an alarm system, and 15 microcomputers; a 2,000-square-foot planetarium; greenhouses and vivariums; a 25 -acre farm with an air-conditioned meeting room for 104 people; a Model United Nations wired for language translation; broadcast capable radio and television studios with an editing and animation lab; a temperature controlled art gallery; movie editing and screening rooms; a 3,500-square-foot dust-free diesel mechanics room;

30. Jenkins v. Missouri, 78 F.3d 1270, $1272-73$ (8th Cir. 1996).

31. See, e.g., Jenkins II, 495 U.S. 33 (1990) (judicially mandated tax increases).

32. See, e.g., Lewis v. Casey, 1996 U.S. LEXIS 4220, at*7-9 (June 24, 1996) (order detailing quality of prison's law libraries and training required for prisoners' legal assistants).

33. See, e.g., Jenkins III, $115 \mathrm{~S}$. Ct. at 2042-45 (order requiring new teacher hiring, school construction, and educational programs).

34. United States v. Montgomery County Bd. of Educ., 395 U.S. 225, 232-34 (1969).

35. Swann v. Charlotte-Mecklenburg Bd. of Educ., 402 U.S. 1, 22-31 (1971).

36. Milliken II, 433 U.S. 267, 288-90 (1977). 
1,875-square-foot elementary school animal rooms for use in a zoo project; swimming pools; and numerous other facilities. ${ }^{37}$

Broad judicial decisionmaking is not limited to the school context, however. In prison cases, for example, federal courts have issued standards concerning how many prisoners are to share each cell, the temperature of the cells, whether they will have televisions or weight-lifting facilities, what they are to eat, and what disciplinary processes are to be used.$^{38}$

Federal courts have employed structural injunctions not only to end the de jure aspects of the constitutional violation, but also to restore the members of the class to the same position in which they would have been but for the constitutional violation. As the Court has declared in its desegregation cases, a desegregation remedy "is necessarily designed, as all remedies are, to restore the victims of discriminatory conduct to the position they would have occupied in the absence of such conduct. ${ }^{39}$ Federal courts are not only to prohibit the enforcement of unconstitutional laws, they are to engage in affirmative reform that will eliminate the continuing effects of past violations. As the Court has described the task, "all vestiges" of the constitutional violation must be eliminated "to the extent practicable."40

In the state institutional context, however, this is a difficult task indeed. How does one estimate where a student would have been but for segregation? What if the court believes that segregation spurred other social effects that have compounded the harms of segregation? The difficulties in answering these questions may lead the federal court to render overbroad, overreaching decrees in an attempt to cure what are essentially social ills. In Jenkins, for example, the district court believed that the de facto segregation of the schools produced "white flight."41 Setting the reversal of white flight as its goal, the district court set out to create a school system so well-equipped and financed, that white families and students would returu to the Kansas City schools. ${ }^{42}$

37. Jenkins II, 495 U.S. 33, 77 (1990) (Kennedy, J., concurring in part and concurring in judgment). The district court even went so far as to address the physical beauty of the schools. Rejecting the state's proposed construction plan, the court stated that:

This 'patch and repair' approach proposed by the State would not achieve suburban comparabihty or the visual attractiveness sought by the Court as it would result in floor coverings with unsightly sections of mismatched carpeting and tile, and individual walls possessing different shades of paint.

Id. at 60-61 (quoting App. to Pet. for Cert. at 70a) (internal quotations omitted).

38. See, e.g., Casey v. Lewis, 43 F.3d 1261 (9th Cir. 1994), rev'd, 1996 U.S. LEXIS 4220 (June 24, 1996); Fletcher, supra note 16, at 639.

39. Milliken v. Bradley, 418 U.S. 717, 746 (1974) (Milliken I).

40. See, e.g., Freeman v. Pitts, 503 U.S. 467, 492 (1992) (quoting Board of Educ. v. Dowell, 498 U.S. 237, 249-50 (1991)) (internal quotations omitted); Swann v. Charlotte-Mecklenburg Bd. of Educ., 402 U.S. 1, 15 (1971).

41. Jenkins III, 115 S. Ct. 2038, 2043 (1995).

42. Id. 
A court's inability to achieve such unattainable social change may result in the retention of jurisdiction over a structural reform case for years, if not decades. As noted before, the district court will usually exercise jurisdiction of the case until the constitutional violation has been cured. If the court defines its remedial goal in terms of reversing social trends and patterns, such as white flight, or in terms of compensating for irreversible losses, such as years spent in poor prison conditions, then there may be no foreseeable termination of the court's supervision of the state institution.

The Supreme Court has attempted to provide guidance on when remedial jurisdiction should be withdrawn, but these factors appear to be rather open-ended. In Freeman $v$. Pitts, ${ }^{43}$ the Court declared that federal courts should continue overseeing desegregation remedies until the institutional defendants have fully complied with the remedial order, retention of jurisdiction is no longer necessary to achieve compliance with the remedy, and the defendants have shown their "good-faith commitment to the whole of the courts' decree and to those provisions of the law and the Constitution that were the predicate for judicial intervention in the first instance." ${ }^{44}$ In Jenkins III, ${ }^{45}$ it seems quite clear that the district court would be unwilling to find that the state or local governments had ever satisfied these criteria. Continuing judicial management of state institutions thus can result in the displacement of the state or the locality as an institution's decisionmakers for some time.

\section{B. How Did We Get Here?}

\section{Judicial Expansion of Remedial Authority}

In administering these structural reform plans, federal trial courts have exercised a wide degree of discretion with little check on their authority. This state of affairs results in part from the doctrinal origins of the federal remedial power. To reverse the evils of entrenched segregation, the Supreme Court found it necessary to authorize the exercise of this extraordinary power to impose affirmative obligations on states and cities. Unfortunately, this change was accompanied by the unwillingness of the federal appellate courts and of the Supreme Court to impose any meaningful limitations upon the district courts' equitable discretion. Appellate courts viewed each remedial plan as unique due to the facts of each case, and they refused to place any significant boundaries on the exercise of remedial power. Analyzing the breadth of the power given to the federal courts and the discretion given for its exer-

43. 503 U.S. 467 (1992).

44. Id. at 491 .

45. 115 S. Ct. 2038 (1995). 
cise will help explain the current state of the federal courts' remedial powers.

Even before Brown II, federal courts had used injunctions to enforce their interpretation of the Constitution, most noticeably during the "ascendancy of the labor injunction" in the late nineteenth century. ${ }^{46}$ In cases such as In re Debs, ${ }^{47}$ and Ex parte Young, ${ }^{48}$ the Court resorted to the injunction to enforce its substantive constitutional policies, whether it was to block strikes as in $D e b s,{ }^{49}$ or to imvalidate state economic regulation as in Young. ${ }^{50}$ Academics, such as then-Professor Felix Frankfurter, sharply criticized the Court's approval of such extraordinary relief in labor cases. ${ }^{51}$ Congress responded by narrowing the judiciary's remedial authority, ${ }^{52}$ and it eventually passed the 1932 Norris-LaGuardia Act, $^{53}$ which prohibited the courts from issuing injunctions in labor disputes altogether.

The scope of the injunctions authorized by the Warren Court exceeded by an entire order of magnitude those of the Progressive Era Court. Attempts to block state economic regulation and private labor actions took the form of negative injunctions that commanded labor unions to cease striking and prohibited state officials from enforcing state economic regulations. ${ }^{54}$ In this respect, the Court followed in the tradition of earlier cases, such as Osborn v. Bank of the United States. ${ }^{55}$ The Osborn Court stated that a federal court "in a proper case in equity, may enjoin a State officer from executing a state law in conflict with the Constitution or a statute of the United States, when such execution will violate the rights of the complainant." involved a private plaintiff who complained of a property loss or of

46. Fiss, supra note 10, at 1-2. For a more complete discussion of the use of the injunction during this period, see PETER C. HopFer, THE LAW'S Conscience: EQuitable CONSTITUTIONALISM IN AMERICA 147-79 (1990). A useful history of the codification of equity in the nation's procedural rules can be found in GARY L. MCDOWELL, EQUiTY AND THE Constitution: The Supreme Court, Equitable Relief, and Public Policy (1982), and in Stephen N. Subrin, How Equity Conquered Common Law: The Federal Rules of Civil Procedure in Historical Perspective, 135 U. PA. L. REv. 909 (1987).

47. 158 U.S. 564 (1895).

48. 209 U.S. 123 (1908).

49. 158 U.S. at 599-600.

50. 209 U.S. at 167.

51. See Frlix Frankfurter \& Nathan Greene, Thr Labor INJUnCtion (1930).

52. Act of Oct. 15, 1914, ch. 323, § 20, 38 Stat. 738 (current version at 29 U.S.C. $\$ 52$ (1988)).

53. Norris-LaGuardia Act, ch. 90, § 1, 47 Stat. 70 (1932) (current version at 29 U.S.C. \& 101 (1994)).

54. See Young, 209 U.S. at 167; Debs, 158 U.S. at 599-600.

55. 22 U.S. (9 Wheat.) 738 (1824).

56. See Davis v. Gray, 83 U.S. (16 Wall.) 203, 220 (1872) (citing Osborn v. Bank of the United States, 24 U.S. (9 Wheat.) 738 (1824)). 
monetary damages due to an unconstitutional state statute..$^{57}$ By the 1930s, however, the equitable power had evolved to permit negative injunctions of statutes that restricted an individual's constitutional rights. ${ }^{58}$

But it was not until 1955 and Brown v. Board of Education (Brown II), ${ }^{59}$ that the Justices expanded the definition of the equity power to include the imposition of affirmative obligations upon states, and the ongoing judicial involvennent and supervision of the remedy. In Brown II, the Court took up the question of how the federal courts were to desegregate the schools in accordance with the mandate of Brown $I$, decided the year before. ${ }^{60}$ Initially, the Court acknowledged the primacy of local school officials in making the educational decisions necessary to implement Brown I: "School authorities have the primary responsibility for elucidating, assessing, and solving these problems."61 Ironically, however, this preference for local control proved to be the ground for remanding the desegregation cases to the district courts, which, "[b]ecause of their proximity to local conditions and the possible need for further hearings, "62 could best monitor local officials' compliance with Brown I. "During this period of transition" to desegregated schools, the Court noted, "the courts will retain jurisdiction of these cases." ${ }^{33}$ These comments set the stage for the scene we see to-

57. See, e.g, Philadelphia Co. v. Stimson, 223 U.S. 605 (1912); Johnson v. Towsley, 80 U.S. (13 Wall.) 72 (1871).

58. Hague v. C.I.O., 307 U.S. 496 (1939); Terrace v. Thompson, 263 U.S. 197 (1923); Truax v. Raich, 239 U.S. 33 (1915).

59. 347 U.S. 483 (1955).

60. The relevant questions presented were:

4. Assuming it is decided that segregation in public schools violates the Fourtcenth Amendment

(a) would a decree necessarily follow providing that, within the limits set by normal geographic school districting, Negro children should forthwith be admitted to schools of their choice, or

(b) may this Court, in the exercise of its equity powers, permit an effective gradual adjustment to be brought about from existing segregated systems to a system not based on color distinctions?

5. On the assumption on which questions $4(a)$ and $(b)$ are based, and assuming furthcr that this Court will exercise its equity powers to the end described in question $4(b)$,

(a) should this Court formulate detailed decrees in these cases;

(b) if so, what specific issues should the decrees reach;

(c) should this Court appoint a special master to hear evidence with a view to recommending specific terms for such decrees;

(d) should this Court remand to the courts of first instance with directions to frame decrees in these cases, and if so what general directions should the decrees of this Court include and what procedures should the courts of first instance follow in arriving at the specific terms of more detailed decrees?

Brown II, 349 U.S. at 298 n.2 (quoting Brown I, 347 U.S. at 495-96, n.I3) (intemal quotations omitted).

61. Id. at 299.

62. Id.

63. Id. at 301 . 
day: district courts exercising continuing control over state institutions for long periods of time.

After determining that the lower federal courts were to have jurisdiction, the Supreme Court described the courts' remedial powers in the broadest terms. The Court surrounded this discussion in the aura of tradition:

In fashioning and effectuating the decrees, the courts will be guided by equitable principles. Traditionally, equity has been characterized by a practical flexibility in shaping its remedies and by a facility for adjusting and reconciling public and private needs. These cases call for the exercise of these traditional attributes of equity power. ${ }^{64}$

The Court authorized the lower courts to enter orders, as they saw fit, that could reach virtually every detail of school administration.

[T] he courts may consider problems related to administration, arising from the physical condition of the school plant, the school transportation system, personnel, revision of school districts and attendance areas into compact units to achieve a system of determining admission to the public schools on a nonracial basis, and revision of local laws and regulations which may be necessary in solving the foregoing problems. ${ }^{65}$

Not only did the Court essentially give the district courts the power to operate a school district, but it also authorized them to revise local laws and regulations to assist in this task. ${ }^{66}$ Perhaps such discretion was justified on the ground that the deprivation of African-American rights throughout the nation demanded the exercise of extraordinary powers

64. Id. at 300 (footnotes omitted).

65. Id. at 300-01.

66. Despite the grant of these sweeping powers, the Court predicted that desegregation would not come swiftly or easily: "Once such a start [toward desegregation] has been made, the courts may find that additional time is necessary to carry out the rulimg in an effective manner." Id. at 300 . Consequently, the Justices permitted the lower courts to implement remedies slowly to take account of public resistance or need. They stated, "Courts of equity may properly take into account the public interest in the elimination of such obstacles [to desegregation] in a systematic and effective manner. But it should go without saying that the vitality of these constitutional principles cannot be allowed to yield simply because of disagreement with them." Id. Thus, while placing the federal courts in the exalted position of administering segregated school systems to achieve desegregation, the Court also allowed the courts to consider the public interests of the segregating states when remedying the harm done to African-American plaintiffs.

Brown thus expanded the discretion of the federal courts at the expense of the states and, indeed, at the expense of African-American plaintiffs, whose interests could be balanced against public resistance to an aggressive desegregation decree. Regardless of whether a federal court, in tailoring its remedy, immediately assumed control over certain school administrative functions or delayed integration to take account of local resistance, it exercised an astounding amount of unchecked and unaccountable discretion. A court's decision to slow down the pace of desegregation, and thus to deny African-American plaintiffs the immediate vindication of their constitutional rights, is no less an exercise of judicial discretion than the setting of a school's budget. 
by the courts. But, as Justice Thomas put it in his Jenkins III ${ }^{67}$ concurrence, "such powers should have been temporary and used only to overcome the widespread resistance to the dictates of the Constitution." ${ }^{\text {"68 }}$ Instead, Brown II ushered in an era in which the extraordinary remedy became ordinary, and $m$ which the unusual exercise of broad power became commonplace.

As federal district courts in segregated areas began to apply Brown $I I$, the Supreme Court did little to restrain them or to impose limitations upon their discretion. In fact, as desegregation progressed slowly in some jurisdictions, the Court sometimes emphasized that change was to be brought about immediately. ${ }^{69}$ In the most significant case involving the scope of the judiciary's reinedial powers, Swann v. CharlotteMecklenburg Board of Education, ${ }^{70}$ the Court established perhaps the most ambiguous standard possible. Articulating a rule that sounds sensible in principle but is largely unhelpful in practice, the Court declared that "the nature of the violation determines the scope of the remedy."

The Court has provided little explication of this Delphic phrase. In Milliken II ${ }^{72}$ for example, the Court declared that the "principle that the nature and scope of the remedy are to be determined by the violation means simply that federal-court decrees must directly address and relate to the constitutional violation itself." how an appellate court can apply such an open-ended phrase in any principled, consistent manner. Whether a remedy "directly address[es] and relate[s] to" a violation often rests in the eye of the beholder, and it is only in the rarest of cases that the appellate courts will overturn a trial court's decree for exceeding the scope of the violation.

Throughout these cases, the Court has continued to reaffirm the sweeping, unchecked nature of the judiciary's remedial powers: "Once a right and a violation have been shown, the scope of a district court's equitable powers to remedy past wrongs is broad, for breadth and flexibility are inherent in equitable remedies." ${ }^{.74}$ Swann repeated Brown II's reliance upon Hecht Co. v. Bowles ${ }^{75}$ for the notion that the equity power permitted courts to mold the remedy to each case and to balance the

67. 115 S. Ct. 2038 (1995).

68. Id. at 2067 (Thomas, J., concurring).

69. See, e.g., Green v. County Sch. Bd., 391 U.S. 430, 439 (1968) ("The burden on a school board today is to come forward with a plan that promises realistically to work, and promises realistically to work now.") (emphasis in original).

70. 402 U.S. 1 (1971).

71. Id. at 16.

72. 433 U.S. 267 (1977).

73. Id. at 281-82.

74. Swann, 402 U.S. at 15.

75. 321 U.S. 321 (1944). 
public and private interest. ${ }^{76}$ Although the Court noted that educational policy lay within the "broad discretionary powers of school authorities," $" 77$ it declared that such decisions would also fall within the remedial authority of a federal court upon a finding of a constitutional violation. As the Court declared, "In default by the school authorities of their obligation to proffer acceptable reinedies, a district court has broad power to fashion a remedy that will assure a unitary school system." Defendant state institutions would be given a chance to cure the constitutional violation by themselves, but if they failed to do so, a federal court could step in to assume all vital decisionmaking.

As desegregation progressed, the Court appeared to become more sensitive to federalism concerns. In 1977, the Court added another principle to the requirement that the scope of the remedy and the nature of the violation be related. The Court held in Milliken II that "the federal courts in devising a remedy must take into account the interests of state and local authorities in managing their own affairs, consistent with the Constitution." ${ }^{\prime 79}$ By 1992, as some desegregation decrees began to wind down, returning authority to state and local officials became a second goal-alongside that of remedying the harms of discrimination-of the equitable remedy ${ }^{80}$ As the Court stated in Jenkins $I I I,{ }^{81}$ the appropriateness of remedial orders:

must rest upon their serving as proper means to the end of restoring the victims of discriminatory conduct to the position they would have occupied in the absence of that conduct and their eventual restoration of "state and local authorities to the control of a school system that is operating in compliance with the Constitution." 182

But this concern about federalism appears to be nothing more than that-a concern. The Court does not appear to have ever invalidated a structural remedy on the ground that it improperly intruded upon the proper authority of state and local institutions. ${ }^{83}$

76. Swann, 402 U.S. at 15 .

77. Id. at 16.

78. Id.

79. 433 U.S. $267,280-81$ (1977).

80. Freeman v. Pitts, 503 U.S. 467, 489-90 (1992).

81. 115 S. Ct. 2038 (1995).

82. Id. at 2049 (quoting Freeman, 503 U.S. at 489).

83. While Jenkins III, 115 S. C. 2038 (1995), and Milliken I, 418 U.S. 717 (1974), did invalidate certain elements of a desegregation remedy, they did so not because the remedy violated state prerogatives, but because the remedy was not tailored to the constitutional violation. Indeed, in both cases, the district courts were permitted to impose broad remedies that continued their intrusion into vital state functions. See, e.g., .Jenkins III, $115 \mathrm{~S}$. Ct. at 2056 (noting that due to court's orders, school district possesses "facilities and opportunities not available anywhere else in the country."); Milliken II, 433 U.S. 267 (1977) (requiring state to bear one-half the costs for compensatory educational programs). 
Courts also seem to find it difficult to identify what aspects of state and local authority should receive the protections of federalism. As we have seen, the Court has approved federal judicial authority over local spending, construction, busing, educational offerings, hiring, and every other aspect of a state institution's operations. ${ }^{84}$ If there is a core attribute of sovereignty into which federal courts cannot intrude, the Supreme Court has yet to identify it. Even if the Court were to identify such a function, the Court's current approach to remedies would not allow a state to exercise absolute autonomy in that area, but instead would balance the state's interest against the need to implement a successful remedy. In such situations, the need for the remedy inevitably trumps the interests of federalism.

In regard to perhaps a state's most central function-taxing its citizens-the Supreme Court has posed few barriers to the exercise of a district court's equitable authority. While the Court in Jenkins II ${ }^{85}$ found that the district court's tax increase order had violated "the principles of comity that must govern the exercise of . . equitable discretion in this area," 86 it did not invalidate the order on the grounds that it was inconsistent with Article III, the Tenth Amendment, or principles of federalism. Instead, the Court held that the district court had gone too far because, rather than impose the tax increase itself, it should have ordered the school district to do so instead. ${ }^{87}$ If state law prohibited such tax increases, the Court concluded, the lower court can enjoin those laws that prevented the school district from increasing taxes. Despite the Court's protest that the "difference between the two approaches is far more than a matter of form," lower courts to impose effective tax increases so long as they act through state officials.

Indeed, the Court's solution in Jenkins $I I$ may prove just as destructive of federalism as the result it reversed. While it prohibits federal courts from directly ordering tax increases, it essentially turns school district officials into nothing more than special masters or magistrates subject to the orders of a federal judge. This part of the decision seems inconsistent with New York $v$. United States ${ }^{89}$ which, although decided in the Commerce Clause context, prohibits the federal government from

Lewis v. Casey, 1996 U.S. LEXIS 4220 (June 24, 1996), may signal a more substantial concern for federalism interests in the future. See infra text accompanying notes 278-87.

84. See supra notes $18-45$ and accompanying text.

85. 495 U.S. 33 (1990).

86. Id. at 50.

87. Id. at 51.

88. Id.

89. 505 U.S. 144 (1992). 
commandeering state officials in this manner. ${ }^{90}$ The tax increases permitted in Jenkins II are even more intrusive than the statute overturned in New York because they allow federal courts to enjoin state laws that bar local officials from raising required taxes. The federal courts may now interfere in the decision, made by the people of a state, on how best to distribute certain powers between state and local government or on whether to give certain powers to its governinent at all." Certainly, if federalism and the Tenth Amendinent mean anything, they must protect a state's decision on how to structure its own system of government.

Thus, from its beginnings in the school desegregation cases, the judiciary's equitable remedial authority has expanded to the point where federal courts in some instances have replaced state and local officials as the managers of state institutions. Challenges to the courts' powers have resulted in only vague limits that impose weak restrictions on efforts to restructure state and local government. As we will see, the Supreme Court's decisions have given insufficient regard to the restraints on the federal judicial power that our federal structure requires.

\section{Academic Reformulation of the Judicial Role-The Judicial Expansion Justified}

It was not only the Supreme Court's opinions that led to the wide acceptance and use of the equity power that we see today. Academics initially praised the expansion of judicial power and provided an intellectually coherent theory to justify the enhanced role of the federal courts. Academic theories have provided additional impetus to the movement to employ broad judicial remedies to reform state institutions.

Academic praise for the growth in remedial power focused upon what was asserted to be a revolutionary reconceptualization of the role of the federal courts in our nation's political system. Courts no longer existed to resolve disputes between private parties involving private or public rights; they were now the agents of public morality. As one article confidently declared, "Adjudication is the social process by which judges give meaning to our public values." ${ }^{, 92}$ The Constitution, or more accurately, Carolene Products' footuote $4,{ }^{93}$ was the expression of these substantive values, and the judge was their interpreter. Judges assumed the central role because, as some proponents of this vision admitted,

90. Id. at 161. But see generally Saikrishna B. Prakash, Field Office Federalism, 79 VA. L Rev. 1957 (1993) (arguing that the framers' intent was to permit the commandeering of state executives and state courts, but not of state legislatures).

91. For example, in Jenkins II, 495 U.S. 33 (1990), the limitation on the school district's authority to raise taxes originated from the state constitution itself. Id. at 38-39.

92. Fiss, supra note 6 , at 2 .

93. United States v. Carolene Products Co., 304 U.S. 144, 152 n.4 (1938). 
"[t]he values that lie at the heart of most structural litigation today ... are not embodied in textually-specific prohibitions," ${ }^{94}$ and judges were needed to tease out these values from an empty text. Nonetheless, one commentator urged, " $[t]$ he absence of textual specificity does not make the values any less real, nor any less important" than the rights and "values" actually enumerated by the Constitution's text. ${ }^{95}$ These unenumerated rights were just as important because they "give our society an identity and inner coherence-its distinctive public morality." 96 Courts became Delphic oracles in a society that seemed to be incapable of either deciding upon its own public values or enforcing them.

These commentators concluded that in a state that has become increasingly bureaucratic and institutionalized, courts should seize upon the structural reform lawsuit as the mechanism whereby they could give practical meaning to our public values. As noted earlier, one article declared that "[t]he structural suit is one in which a judge, confronting a state bureaucracy over values of constitutional dimension, undertakes to restructure the organization to eliminate a threat to those values posed by the present institutional arrangements." ${ }^{.97}$ Under this vision, the new model of the judicial role justified a sweeping transformation of the entire system of adjudication and remedies. Adjudication no longer focused on an event, but on a "social condition." The injured plaintiff was replaced by social groups that relied upon national public interest groups for representation..$^{98}$ The institutional or governinental defendant was no longer truly important because the true wrongdoer was the social process and the institutional dynamics that gave rise to the social condition. Litigation was no longer bipolar; but instead was "sprawling and amorphous" as numerous parties representing different affected groups appeared as joined parties, intervenors, or amici.99

In light of this ambitious vision of adjudication, the scope of the courts' remedial authority becomes critical. Without the actual power to alter institutions and to marshal all of the forces of government behind it, a court would be unable to change the social conditions that violate our public values. A remedy no longer is a one-time event where damages are paid or illegal action is ended. Because a court is attempting to impose public values on an institution, and, through that institution, to the larger society, its remedial power is used constantly over time. As one article put it: "The remedial phase in structural litiga-

\footnotetext{
94. Fiss, supra note 6, at 11.

95. Id.

96. Id.

97. Id. at 2.

98. See Chayes, supra note 6, at 1291.

99. Id. at 1284, 1289-1302.
} 
tion ... involves a long, continuous relationship between the judge and the institution." 100 A reinedy may have no end, and a judge may have no limit in her authority over the state and its institutions: "A long term supervisory relationship develops between the judge and the institution, for performance must be inonitored, and new strategies devised for making certain that the operation of the organization is kept within constitutional bounds."

This intellectual commentary has ignored the structural concerns that the Supreine Court has mentioned but has rarely, if ever, enforced. Perhaps the supporters of expansive remedies were correct that federal courts could play a leading role in articulating public values. And perhaps they were correct that broad remedial powers were necessary to translate these values imto reality. But like the courts, these commentators never questioned whether it was constitutionally appropriate for the courts to play this role. Both should have asked first whether the Constitution's principles of federalism and separation of powers permitted the federal courts to engage in activities that were very different from the normal process of adjudication. It is to these questions that I will now turn.

\section{II}

Federal Remedial Authority and the Functional Role OF THE COURTS

\section{A. Functional Difficulties with the Judicial Supervision of State Institutions}

Before I address the constitutional difficulties with the extensive use of far-reaching and invasive equitable remedies, I will examine the practical difficulties courts have experienced in managing institutions. Courts, soine critics have argued, simply are functionally incapable of addressing "polycentric" problems that involve many different factors and relationships. ${ }^{102}$ Case studies have found that courts experience great difficulty in weighing policy alternatives and in calculating costs and benefits. ${ }^{103}$ Courts were shown to be unable to gather and to absorb the sort of sufficient, objective data required to make considered decisions. ${ }^{104}$ In terins of institutional competence, legislatures and bureaucracies appeared much better suited for these tasks.

To put it differently, courts are structurally worse off than other arms of government at developing an intellectually coherent solution to

100. Fiss, supra note 6, at 27.

101. Id. at 28.

102. Fuller, supra note 15 , at 394-404.

103. HoROwitz, supra note 15 , at 257.

104. Id. at 274-84. 
social problems. While courts are expert at determining historical fact and causation, structural remedies call upon them to engage in very different activities. They must conduct social fact-finding and must discover and address the political, economic, and social factors that may have created an unconstitutional condition. ${ }^{\text {tos }}$ Formulating the correct remedy requires courts to predict how the remedy will affect, and be affected by, the political, economic, and social context within which it is implemented. Courts are ill-suited for these tasks because they have little experience or facility for operating or administering complex institutions and social programs. ${ }^{106}$

Once a decree is decided upon, courts have proven ineffective at implementing their structural remedies. Courts possess only imperfect tools for communicating their decrees, and, in fact, they usually mnst rely upon the personnel of the institutional defendant to disseminate and to implement their orders. ${ }^{107}$ In perhaps the sharpest contrast with bureaucracies and legislatures, courts have few resources for guaranteeing compliance on the part of the defendants or for creating positive incentives to encourage adherence to judicial orders. Aside from the threat of a contempt order, courts must rely upon the moral persuasiveness of their judgments to acquire legitimacy. This highlights another deficiency in a court's ability to implement a remedy: its lack of resources for marshaling political and public support for its decrees, without which the court's efforts likely will fail. ${ }^{108}$ If courts inject themselves into the political arena, they risk undermining the impartiality and moral authority they need to persuade others to support their orders.

Jenkins $I I I^{109}$ provides a compelling example of a federal court's inability to contend with the multiplicity of factors, causes, and relationships that have led to an allegedly unconstitutional condition. In 1984, the district court attributed the disproportionately high levels of African-American students in the KCMSD of 1984 to white flight, which it found to be a "vestige" of the state-enforced segregation in force thirty years before. ${ }^{110}$ According to the court, the KCMSD's failure to integrate led to a "general attitude of inferiority" and to "low achievement" on the part of African-American students. II The district court provided little evidence for its fact-finding on this point, and it did not examine the degree to which other factors, such as

105. ScHUCK, supra note 15 , at 156-61.

106. Id. at 158.

107. Id. at 162 .

108. Id. at 167.

109. 115 S. Ct. 2038 (1995).

110. Jenkins v. Missouri, 593 F. Supp. 1485, 1503-06 (W.D. Mo. 1984).

111. Id. at 1492 . 
demographic trends or economic shifts out of the inner city, had contributed to the high concentration of African-American students. ${ }^{12}$ Whether segregation in 1954 had produced white flight and the "racial isolation" of the KCMSD in 1984 would be a difficult determination for a social scientist to make, not to mention a district court judge. As the Court had warned in the earlier case of Freeman v. Pitts, ${ }^{113}$ "It is simply not always the case that demographic forces causing population change bear any real and substantial relation to a de jure violation." 114

Jenkins III not only provides an example of a court's difficulty in making determinations of causation when larger social factors are involved, but it also shows how remedies often will fail to achieve goals that are linked to the reversal of social and demographic conditions. Having decided that white flight had produced the constitutional violation, the district court designed its remedy to bring whites back into Kansas City. ${ }^{115}$ To reach its goals of reversing white flight and improving African-Americans' academic perfornance, the district court ordered the creation of special magnet schools, the construction of new multimillion dollar facilities, the hiring of new faculty, and the development of special educational programs. ${ }^{16}$

When these programs were implemented, however, they did not produce the desired results. Whites did not return to the school district in any significant numbers, and African-American test scores did not reach national averages. It is quite likely that the failure of the remedy arose because the district court, understandably, could not identify what factors would reverse white flight or would improve African-American academic achievement. Even if the court could discover the proper method for achieving its goals, it could not necessarily implement it. A court simply does not have the power over the economic imperativesfor example, whether the city can offer attractive jobs or affordable housing - that exert a great influence upon a family's decision where to live, and hence, where their children will attend school. As the Court has recognized, "It is beyond the authority and beyond the practical ability of the federal courts to try to counteract these kinds of continuous and massive demographic shifts." 117

112. In fact, it would seem that white flight would be the product of desegregative efforts, rather than the result of failures to desegregate.

113. 503 U.S. 467 (1992).

114. Id. at 496.

115. Jenkins v. Missouri, 639 F. Supp. 19, 26-46 (W.D. Mo. 1985), aff'd, 807 F.2d 657 (8th Cir. 1986), cert. denied, 484 U.S. 816 (1987).

116. Id.

117. Freeman, 503 U.S. at 495. 


\section{B. Federalism and Separation of Powers Concerns With the New Institutional Litigation}

The practical difficulties courts have experienced in implementing structural reforms point to deeper problems with the enterprise of federal remedial power. Several anthors have criticized the judicial management of state institutions on both federalism and separation of powers grounds..$^{118}$ According to these observers, structural reform decrees have invaded a core area of state responsibility guaranteed by the Tenth Amendment. Further, as these critics have argued, even if the federal government had the authority to seize control of a state institution, prudential considerations should weigh against an active judicial role in supervising day-to-day operations. While these writers have been critical of this type of judicial management, they have questioned only the scope and exercise of the judiciary's power, rather than its roots.

These critics have pointed out that federalism and separation of powers are interrelated doctrines. Both principles act to place limits on what the federal courts can do, but in issuing structural reform decrees, federal jndges have been evading these restrictions. In the course of attempting to remedy constitutional violations, the federal courts not only have tread upon principles of federalisin, but they also have employed procedures that undermine the impartiality of the federal judiciary. In imposing institutional remedies, courts have set spending priorities for state governments, and then have inplemented those priorities by specifying how the funds are to be spent. Federal courts have infringed on the core state prerogatives to allocate resources, to decide on policies, and, ultimately, to manage their own governments. Worse yet, these transgressions have occurred in areas, such as education, that the Supreme Court has recognized as traditionally falling under state control. ${ }^{119}$

Critics' concerns that these courts have not been properly aware of the separation of powers issues involved touch on a difficult aspect of the problem. The problem is not that federal, rather than state, actors are running state institutions, but rather that members of the federal judiciary are performing tasks better left to the political branches. Supervising and controlling the everyday operations of a hospital, school, or prison are executive and legislative, rather than judicial, functions. By assuming such powers, courts threaten to circumvent democratic decisionmaking processes and to transform themselves into roving cominis-

118. See generally Gerald E. Frug, The Judicial Power of the Purse, 126 U. PA. L. Rev. 715 (1978); Mishkin, supra note 15; Nagel, supra note 15.

119. Jenkins III, 115 S. C. 2038, 2054 (1995) ("our cases recognize that local autonomy of school districts is a vital national tradition") (citing Dayton Bd. of Educ. v. Brinkman, 433 U.S. 406, 410 (1977)); see also Frug, supra note 118, at 743-49; Mishkin, supra note 15, at 967-71. 
sions whose aim is to "do the right thing," rather than to interpret and to enforce the law. As one observer warned early in 1978, "issuing orders of this kind as a regular inatter in the ordinary course of business" threatened to bring into question the very "legitimacy of the federal courts." 120

In Jenkins III, the Court indicated that it is becoming aware of the inherent limitations upon the equity powers of the federal courts. As Justice O'Connor stated, "The necessary restrictions on [the Court's] jurisdiction and authority contained in Article III of the Constitution limit the judiciary's institutional capacity to prescribe palliatives for societal ills." 21 Or, as Justice Thomas declared, "[W] hat the federal courts cannot do at the federal level they cannot do against the States; in either case, Article III courts are constrained by the inherent constitutional limitations on their powers."122 The remainder of this Article will attempt to show that these Justices' comments are supported by the textual, structural, and historical context of the federal courts' equitable powers.

\section{III}

\section{Equitable Remedies and Separation of Powers}

In this Part, I will examine how the Constitution's separation of powers limits the federal courts' equitable authority. I will review the separation of powers principles inherent in the Constitution's structure and the framers' concerns about the extent and nature of the federal judicial power. I then will discuss how these structural rules constrain the federal courts' ability to employ equitable remedies. This analysis will suggest that the federal courts have no inherent authority to exercise equitable remedies, and that even with congressional approval, certain exercises of the remedial power lie outside of the judiciary's Article III powers.

120. Mishkin, supra note 15, at 950. According to these critics, however, the solution was not to turn away from judicial power, but only to constrain its use. Federal courts could continue to issue decrees, they argued, but should refrain from issuing ones of great specificity. Courts should defer to state executive agencies for help in formulating their decrees, make a special showing to justify decrees of a particularly broad scope, and attempt to cooperate with the other branches of the federal government. See Nagel, supra note 15, at 706-23. Ultimately, federal courts should allow majoritarian institutions at the state and federal level the opportunity to cure the violation before wielding their great powers, either by including state governments in the decree-formulating process, or by seeking assistance from the other branches of the federal government. Cf. Mishkin, supra note 15 , at 976 "'I beheve the federal courts can serve an extremely valuable role in setting perimeters of decency within which the majoritarian processes must work. But the way to achieve desirable goals - and the only way to do so lastingly-is through the democratic political processes which must remain the core of our polity.").

121. Jenkins III, $115 \mathrm{~S}$. Ct. at $206 \mathrm{I}$ (O'Connor, J., concurring).

122. Id. at 2070-71 (Thomas, J., concurring). 
This is not to say that constitutional violations should go unredressed. Many citizens have suffered, and no doubt continue to suffer, illegal encroachments on their constitutional rights. When a constitutional right has been violated, both the federal government and the state governments have an obligation to implement a remedy. But the government's duty to right a constitutional wrong does not permit the federal judiciary to exceed its authority, no matter how just the cause. Even if the judiciary cannot act, the political branches and the states canindeed, they have a constitutional duty to do so. However, should there be a remedy that requires power that the federal government as a whole does not possess, then the only solution is for the people to amend the Constitution to vest the central government with that authority.

Just as the Constitution enumerates the powers of the federal government vis-à-vis the states, the Constitution also establishes three branches of government and limits the nature of the authority that each of those entities may exercise. Consistent with the purpose of a written constitution, these limits and functions are fixed and cannot change. The scope and nature of a branch's power cannot expand simply because the actions of one federal branch affects a governmental entity outside of the federal government-instead of within the federal government. If the judiciary cannot take a certain action that infringes upon the authority of the federal executive or legislative branches, it cannot suddenly undertake the same action when a state government is the subject of that action.

\section{A. The Constitution, the Separation of Powers, and the Judicial Power}

While a full review of the separation of powers is beyond the scope of this Article, an overview of the framing of the Constitution will provide sufficient background for a discussion of the judicial power. This Part seeks to determine the original understanding of the judicial power and its relationship to constitutional remedies. By original understanding, I mean that the text of the Constitution must be interpreted in the context of the understanding of those who ratified it. Of course, our starting point remains the constitutional text. But if the text, when construed in light of other parts of the Constitution, remains ambiguous, the next step is to examine the constitutional debates, treatises, and other public documents concerning the Constitution that existed at the time of ratification. These sources provide the legal context from which the ratifiers of the Constitution would have interpreted the text before them. Private and secret discnssions and statements, while less relevant, will be examined when they illuminate the meaning of a provision at the time of ratification. While post-ratification evidence could not have affected the framers' understanding, it can provide marginal help in confirming 
that a certain understanding was generally held both before and after the ratification of the Constitution. ${ }^{123}$ Even if one does not agree that the original understanding should control our interpretation of the Constitution, at the very least the history behind the provisions should inform and illuminate our own understanding of the constitutional text.

\section{The Separation of Powers, Generally}

In establishing a national political system composed of several state governments and of a single federal government, the Constitution relied on the principle of popular sovereignty: the American people, rather than a monarch or the government, were sovereign, and both the federal and state governments served only as their agents. ${ }^{124}$ Speaking through the federal and state constitutions, the people limited the powers of their governments. Indeed, one of a written constitution's primary purposes is to clearly delineate the powers delegated to a government and its branches. Unlike popular rights, which the Ninth Amendment left undefined and open-ended, ${ }^{125}$ the powers of the federal government were strictly enumerated and closed to future expansion by the Tenth Amendment: "The powers not delegated to the United States by the Constitution, nor prohibited by it to the States, are reserved to the States respectively, or to the people."126

Written restrictions were not the only check on a central government that might be tempted to abuse its powers. To effectuate popular sovereignty, the framers designed a democratically-accountable federal government so that the people could dictate the decisions on critical government functions, such as spending, taxation, or war. "[T] he two greatest securities [the people] can have for the faithful exercise of any delegated power," Publius told the voters of New York, are "the restraints of public opinion" and "the opportunity of discovering with

123. For a fuller discussion of this methodology, see John C. Yoo, The Continuation of Politics by Other Means: The Original Understanding of the War Power, 84 CALIF. L. Rev. 167 (1996). See also McIntyre v. Ohio Elections Comm'n, 115 S. Ct. 1511, 1529-30 (1995) (Thomas, J., concurring); U.S. Term Limits, Inc. v. Thornton, 115 S. Ct. 1842, 1880 (1995) (Thomas, J., dissenting); Harmelin v. Michigan, 501 U.S. 957, 982-85 (1991); Robert H. Bork, The Tempting of America 143-60 (1990); Steven G. Calabresi \& Saikrishna B. Prakasl,. The President's Power To Execute the Laws, 104 YALE L.J. 541, 550-59 (1994).

124. See The Federalist No. 78, at 525 (Alexander Hamilton) (Jacob E. Cooke ed., 1961) [lereinafter Federalist No. 78]; Akhil R. Amar, Of Sovereignty and Federalism, 96 YALE L.J. 1425, 1448-51 (1987).

125. For a more general discussion of the Ninth Amendment, see Suzanna Sherry, The Founders' Unwritten Constitution, 54 U. CHI. L. REv. 1127 (1987); John C. Yoo, Our Declaratory Ninth Amendment, 42 EMORY L.J. 967 (1993).

126. U.S. CONST. amend. X. See generally Amar, supra note 124. But see JESSE H. ChOPER, Judicial Review and the National Political Process (1980); Herbert Wechsler, The Political Safeguards of Federalism: The Role of the States in the Composition and Selection of the National Government, 54 Colum. L. REv. 543 (1954). 
facility and clearness the misconduct of the persons they trust, in order either to their removal from office, or to their actual punishment."127 The approval of the people was the ultimate check upon the threat of an abuse of power by their elected representatives.

In addition to the check of a written constitution and of democratic representation, the framers added another safeguard against government tyranny: the separation of powers. The framers were profoundly influenced by Montesquieu's belief that the executive, legislative, and judicial powers must be kept distinct. In his Federalist No. 47, James Madison extensively quoted Montesquieu to defend the Constitution's separation of powers: "Were the power of judging joined with the legislative, the life and liberty of the subject would be exposed to arbitrary controul, for the judge would then be the legislator. Were it joined to the executive power, the judge might behave with all the violence of an oppressor."128 The framers also had learned firsthand the excesses that could occur within the states if one branch, the legislature, were to dominate the other two. ${ }^{129}$ When they drafted and ratified the Constitution, the framers were determined to prevent a single branch from assuming the powers of the other two. ${ }^{130}$

\section{The Separation of Powers and the Judicial Power}

To this end, the Constitution explicitly vested the executive, legislative, and judicial power in three distinct, independent branches of government. ${ }^{131}$ Congress is vested with "All legislative Powers herein granted," 132 wlich includes the power to tax and spend, to regulate interstate commerce, and to constitute the lower federal courts. ${ }^{133}$ The

127. The Federalist No. 70, at 477-78 (Alexander Hamilton) (Jacob E. Cooke ed, 1961).

128. The Federalist No. 47, at 326 (James Madison) (Jacob E. Cooke ed., 1961) (internal quotations omitted).

129. When they drafted and ratified the Constitution, the framers had before them the excesses produced by legislative dominance of the other branches. See WiLLI P. ADAMS, THE FIrST American Constitutions: Republican Ideology and the Making of the State ConstiTUTIONS IN THE REVOLUTIONARY ERA 271 (Rita Kimber \& Robert Kimber trans., 1980); Yoo, supra note 123.

130. Indeed, some state ratifying conventions criticized the Constitution for not explicitly delineating the separation of powers. For example, the Virginia ratifying convention included among its proposed amendments to the Constitution the declaration that "the legislative, executive, and judicial powers of government should be separate and distinct." 2 BERNARD SCHWARTZ, THE BiLL OF RIGHTS: A DOCUMENTARY History 841 (1971). Although James Madison's initial draft of the Bill of Rights included a separation of powers provision, it was deleted by the Senate. It appears that it was deleted because it was thought unnecessary. Id. at 1117 (comments of Roger Sherman).

131. To be sure, the Constitution blended some of the functions of the branches in order to provide checks and balances; thus, the President has a veto, the Senate ratifies treaties, and Congress impeaches. But where the Constitution provides for such mixtures of authority, its explicit description of the arrangement makes clear that they are only exceptions to the general vesting clauses.

132. U.S. CoNST. art. I, \& 1.

133. Id. $\$ 8$. 
President exercises the "executive Power," 134 which includes the power to act as Commander-in-Chief, to issue pardons, and to "take Care that the Laws be faithfully executed."135

Article III of the Constitution vests the "judicial Power of the United States" in the Supreme Court and any inferior courts established by Congress. ${ }^{136}$ Article III also carefully enumerates the situations in which the federal courts may exercise the judicial power: cases arising under federal law, cases involving ambassadors, cases of admiralty, controversies in which the United States is a party, controversies between citizens of different states, and controversies between citizens of the same state concerning land grants in different states. ${ }^{137}$ Articles II and III, unlike Article I, do not simply define the nature of the powers granted; they also vest the President and the federal courts with an undefined "executive" and "judicial" power, respectively.

This reading of Article II has been challenged by critics of the unitary presidency. These commentators argue that Article II, Section 1 's declaration that the executive power "shall be vested" in the President does not convey an independent grant of power to the President. ${ }^{138}$ Instead, they read the subsequent sections of Article II as enumerating the executive powers granted to the President; in other words, Article II itself defines what Article II means by the "executive Power" in the same way that Article I defines what is meant by the "legislative Power." If transplanted to the Article III context, this argument would suggest that the judicial power granted to the federal courts in Article III, Section 1 is merely a reference to the powers enumerated in the rest of Article III. It is the remaining portion of Article III-particularly the phrase that the judicial power "shall extend to" federal cases-and not Article III, Section 1, that thus would define the "judicial Power."

If this interpretation were correct, then Congress would exercise great discretion in structuring and controlling both the executive and judicial branches and the powers each would exercise. In the absence of an inherent executive power, for example, Congress could structure the federal agencies in almost any manner it chose. So long as it did not interfere with the President's enumerated powers, Congress could con-

134. Id. at art. II, § 1 .

135. Id. $\S \S 2,3$.

136. Id. at art. III, $\S 1$.

137. Id. \&2. On the importance of the difference between "cases" and "controversies," and their relationship to the judicial power, see Akhil R. Amar, A Neo-Federalist View of Article III: Separating the Two Tiers of Federal Jurisdiction, 65 B.U. L. Rev. 205, 229-30 (1985).

138. See A. Michael Froomkin, The Imperial Presidency's New Vestments, 88 Nw. U. L. REv. 1346, 1358-62 (1994); Lawrence Lessig \& Cass R. Sunstein, The President and the Administration, 94 Colum. L. Rev. 1 (1994). But see Steven G. Calabresi, The Vesting Clauses as Power Grants, 88 Nw. U. L. Rev. 1377, 1395-1400 (1994); Calabresi \& Prakash, supra note 123, at 570-72. 
ceivably insulate executive officers from presidential removal, among other things. Similarly, if the "judicial Power" merely describes the authority explicitly granted in the other sections of Article III, then we would be forced to conclude that the federal courts possessed minimal inherent powers. This would leave questions concerning the power and structure of the federal courts within the discretion of Congress, which is given the power to establish the lower federal courts.

Those who read Article II and Article III as granting independent power beyond those authorities listed in subsequent sections of the articles clearly have the better of the argument. Article III would make little sense if read in the manner that critics of the unitary executive read Article II. ${ }^{139}$ Sections 2 and 3 of Article III do nothing to define or to describe what the Constitution means by the "judicial Power." Indeed, Section 2 only describes the classes of cases upon which the federal courts may exercise their judicial power. Section 2's statement that the "judicial Power shall extend to all Cases" presumes that the judicial power already exists.

If one agrees with the critics of independent Article II and Article III powers, then this Article's inquiry is basically at an end. The courts simply could not exercise inherent remedial authority if there were no inherent judicial authority to do so. Since Congress has never provided federal courts with the explicit authority to impose structural injunctions upon state institutions, then this Article's conclusion will have been quickly reached.

However, because the better analysis indicates that the judicial power is not enumerated within Article III, one must press forward. The next step is to ask whether the Constitution permits the branches to exercise power that goes beyond the Constitution's specific enumerations. To start with, there are important differences in the clauses that vest power in Congress, the President, and the Supreme Court. Article I states that Congress receives "[a]11 legislative Powers herein granted," which indicates that the House and Senate could exercise only those powers enumerated in Article I. Articles II and III, however, avoid the "herein granted" language in favor of undefined grants of the "executive Power" and of the "judicial Power." This difference in the text suggests that the President and the Supreme Court are not limited to the powers listed in Articles II and III, but instead must exercise the full powers of their branches-hence the use of "shall," rather than

139. Calabresi, supra note 138 , at $1378-89$. 
"may," be vested-subject only to the limitations and exceptions in other parts of the Constitution. ${ }^{140}$

The Constitution creates three important limitations on the judicial power. First, Article III, Section 2 strictly limits what type of cases and controversies to which the judicial power extends. Second, Section 2 describes what level of federal court is to hear what types of cases. For instance, the Supreme Court has original jurisdiction over those cases involving states or ambassadors as parties, and appellate jurisdiction over the rest of the cases listed in Article III. Third, the Constitution gives Congress the power to establish and structure the lower federal courts ${ }^{141}$ and to regulate the appellate jurisdiction of the Supreme Court. ${ }^{142}$

It is important to understand that Article III's enumeration of federal cases and controversies does not define the judicial power. Professor Akhil Amar notes that the judicial power "goes beyond mere subject matter jurisdiction."143 Indeed, I would submit that the judicial power is everything but subject matter jurisdiction. Article III, Section 2 lists only the types of cases and controversies upon which the judicial power can be used, but does not define what that judicial power is.

Thus, a supporter of the equitable remedial power who seeks justification in Article III, Section 2's mention of "Law and Equity"144 would be mistaken. Section 2 does not authorize the federal courts to exercise equitable powers; it only states that the federal courts' jurisdiction shall include all federal question cases, from either courts of law or courts of equity. If the federal courts can exercise equitable powers, therefore, it is only because equitable powers are contained in the judicial power conveyed by Article III, Section 1 .

Therefore, to determine whether the federal courts have equitable powers, one must first determine what the Constitution means by " $[t]$ he judicial Power of the United States." Article III's failure to define the judicial power, however, does not necessarily translate into an open-

140. For a fuller elaboration of this point, see Calabresi \& Prakash, supra note 123, at 570-81; Steven G. Calabresi \& Kevin H. Rhodes, The Structural Constitution: Unitary Executive, Plural Judiciary, 105 HARv. L. Rev. 1153, 1175-86 (1992).

141. The Constitution mentions Congress' plenary power to establish the lower courts twice. "The judicial Power of the United States, shall be vested in one supreme Court, and in such inferior Courts as the Congress may from time to time ordain and establish." U.S. ConsT. art. III, § 1. "The Congress shall have Power... To constitute Tribunals inferior to the supreme Court." U.S. ConsT. art. I, $\S 8$.

142. "In all the other Cases before mentioned, the supreme Court slall have appellate Jurisdiction, both as to Law and Fact, with sucli Exceptions, and under such Regulations as the Congress shall make." U.S. CoNST. art. III, \$ 2.

143. Amar, supra note 137, at 233.

144. "The judicial Power shall extend to all Cases, in Law and Equity, arising under this Constitution, the Laws of the United States, and Treaties made, or whicl shall be made, under their Authority." U.S. CoNST. art. III, § 2. 
ended power grant. ${ }^{145}$ It would be a mistake to read the Constitution's structure as permitting a branch to engage in a function that lay outside its textually defined authority, even if that exercise of power does not intrude into the "core functions" of another branch. ${ }^{146}$ The relevant inquiry is not whether the judiciary's action intrudes upon the proper functioning of the President and of Congress, but rather whether the action is a legitimate exercise of the judicial power.

The remainder of this Article attempts to sketch the judicial power's general boundaries and to identify what functions it does and does not include. ${ }^{147}$ At a minimum, one can assume that it encompasses the power of the federal courts to decide cases and controversies that parties litigate before them. As a necessary component of this casedeciding function, the courts must have the power to interpret the law. As Chief Justice John Marshall declared, "It is emphatically the province and duty of the judicial department to say what the law is." 148 Publius explained in The Federalist No. 78 that "[t]he interpretation of the laws is the proper and peculiar province of the courts." 149 The Federalist No. 78 also divined from the structure of the Constitution the principle that the judicial power includes the power of judicial review.

The judicial power also includes the right, in the words of Professor Amar, "to speak in the name of the nation, to speak definitively and finally," at least in regard to questions of federal law. ${ }^{150}$ We can infer this attribute of the judicial power from the Supremacy Clause, ${ }^{151}$ from Article III's requirement that the judicial power extend to federal question cases, ${ }^{152}$ and from the creation of an independent federal judiciary. ${ }^{153}$ In addition, the federal courts exercise "certain implied powers" that "must necessarily result to our Courts of justice from the nature of their institution," such as the power to sanction and the authority to set

145. Whatever the judicial power contains is all that the Supreme Court may exercise. Obviously, the Court cannot exercise the legislative power or the executive power, just as Congress cannot exercise the executive power and the President cannot exercise the judicial power-each of these powers is given textually to a different, independent branch of government. The Constitution's separation of powers not only establishes three distinct branches of government, it also limits the nature of the authority that each branch can wield.

146. For examples of what I believe is a misguided approach to the separation of powers, see Mistretta v. United States, 488 U.S. 361, 380-84 (1989) (upholding the Federal Sentencing Guidelines), and Morrison v. Olson, 487 U.S. 654, $693-96$ (1988) (upholding the appointment of independent counsel).

147. The author examines the extent and nature of the inherent judicial power in greater detail $\ln$ a forthcoming article.

148. Marbury v. Madison, 5 U.S. (1 Cranch) 137, 177 (1803).

149. FEDERALIST No. 78, supra note 124, at 525.

150. Amar, supra note 137, at 233.

151. U.S. CoNST. art. VI, \& 2.

152. Id. at art. III, \& 2 .

153. Id. at art. VI, \& 1 . 
rules governing their internal functions. ${ }^{154}$ Even though the federal courts may possess these inherent powers, neither the text nor the structure of the Constitution compels the conclusion that the federal courts possess the inherent authority to impose equitable remedies upon the states. Given the states' significance in the national political system, one would expect the text to explicitly authorize the courts to impose remedies that so intrude into a state's sovereignty if such were the framers' plan.

The problem with judicial equitable powers is the manner in which structural injunctions "can be used essentially to bypass majoritarian political controls." Uns Ulike the other elements of the federal and state governments, federal judges have no political accountability to the community in which their policy decisions are executed; indeed, once appointed, they are not accountable to anyone. This unaccountability treads upon the Tenth Amendment's fundamental reservation of rights and powers to the states and people, and the Constitution's structure of enumerated powers. Furthermore, when the Constitution removes certain decisions from the democratic processes of the states, it does so explicitly in the Constitution's text. ${ }^{156}$

In all other cases, as declared by the Tenth Amendment, the states continued to exercise all of the "powers not delegated to the United States by the Constitution, nor prohibited by it to the States."157 Regardless of whether one believes that sovereign immunity emanates from the Eleventh Amendment, ${ }^{158}$ or from the very structure of the

154. United States v. Hudson \& Goodwin, 11 U.S. (7 Cranch) 32, 34 (1812); see also Chambers v. NASCO, Inc., 501 U.S. 32, 43-46 (1991) (holding that the district court had inherent power to assess attorneys' fees); Young v. United States ex rel. Vuitton et Fils S.A., 481 U.S. 787, 800-01 (1987) (holding that the district court had authority to appoint private attorneys to initiate contempt proceedings).

Whether the judicial power also includes the power to interpret the Constitution definitively and exclusively is a subject open to some debate. Despite the language of Marbury and of Cooper $v$. Aaron, 358 U.S. 1, 18 (1958) ("the federal judiciary is supreme in the exposition of the law of the Constitution"), there is little textual or structural support for the idea that the Supreme Court's interpretation of the Constitution is on a par with the Constitution itself. Instead, the Constitution, with its creation of three, equal, coordinate bodies, seems to permit each branch to interpret the Constitution in the course of its enumerated duties. The adoption of the idea that the Supreme Court is the final expositor of the Constitution would place an even more compelling obligation upon the other branches to carry out the Court's decrees.

155. Mishkin, supra note 15 , at 958 .

156. See, e.g., U.S. CoNST. art. I, $\S 10$ (prohibiting states from, among other things, entering into treaties, coining money, passing ex post facto laws, impairing contracts, or maintaining troops without the consent of Congress).

157. U.S. CoNsT. amend. X.

158. See, e.g., Hans v. Louisiana, 134 U.S. 1, 4-6 (1890). Historically, the Eleventh Amendment appears only to have been intended to eliminate state-party jurisdiction, rather than to codify sovereign immunity. See Amar, supra note 124, at 1473-84; Wiliam A. Fletcher, A Historical Interpretation of the Eleventh Amendment: A Narrow Construction of an Affirmative Grant of Jurisdiction Rather than a Prohibition Against Jurisdiction, 35 StaN. L. REv. 1033, 1045-63 (1983). 
Constitution, ${ }^{159}$ it seems clear that the Constitution, especially the Tenth Amendment, recognizes that the federal government and the federal judiciary cannot intrude into certain core functions of the states. ${ }^{160}$ Yet structural reform injunctions often directly interfere with these areas of state discretion by stripping state governments of some of their most basic responsibilities.

The text and structure of the Constitution, as well as the continuing significance of the states in the national political system, suggest that the burden of proof rests upon the supporters of broad remedial powers to demonstrate that the frainers understood Article III to vest the federal courts with this authority. In the next Section, I will examine the framers' understanding of the judicial power. I will show that no consensns existed among the ratifiers of the Constitution that the federal courts could impose equitable remedies upon the states. In fact, the available

159. This appears to have been the view of Publius, who argued before passage of the Eleventh Amendment that the states' inherent sovereignty immunized them from suit:

It is inherent in the nature of sovereignty, not to be amenable to the suit of an individual without its consent. This is the general sense and the general practice of mankind; and the exemption, as one of the attributes of sovereignty, is now enjoyed by the government of every state in the union. Unless therefore, there is a sumender of this immunity in the plan of the convention, it will remain with the states, and the danger intimated must be merely ideal.

The Federalist No. 81, at 548-49 (Alexander Hamilton) (Jacob Cooke ed., 1961) [hereinafter Federalist No. 81].

The framers believed that great areas of potential litigation between the states and individuals would arise from public contracts, probably those concerning debts incurred during the Revolutionary War. In a sense, these cases were the forebears of modern structural reform cases, because the question of how to pay off state debts not only involved many creditors, but also involved questions regarding public funding and taxation. Like today's structural reform cases, they even involved questions of constitutional rights, in this case the contract clause. U.S. CoNST. art. I, $\S 10$ ("No State shall ... pass any ... Law impairing the Obligation of Contracts ....").

- In this context, Publius clearly argued that the Constitution did not infringe on the sovcreign immunity of the states from suit:

The contracts between a nation and individuals are only binding on the conscience of the sovereign, and have no pretensions to a compulsive force. They confer no riglit of action independent of the sovereign will. To what purpose would it be to authorise suits against states, for the debts they owe? How could recoveries be enforced? It is evident that it could not be done without waging war against the contracting state; and to ascribe to the federal courts, by mere implication, and in destruction of a pre-existing right of the state governments, a power which would involve such a consequence, would be altogether forced and unwarrantable.

FEDERALIST No. 81, supra, at 549.

160. Indeed, in The Federalist No. 81, Publius suggested that states would retain their sovereignty and would have the freedom to choose how to satisfy judgments against them. As he put it, "[T] here is no colour to pretend that the state governments, would by the adoption of [the Constitution], be divested of the privilege of paying their own debts in their own way, free from every constraint but that which flows from the obligations of good faith." FEDERALIST No. 81, supra note 159, at 549. Although Publius was speaking about private parties' ability to enforce contracts made with a state, which the framers anticipated would constitute the great majority of disputes between individuals and state governments, the principle he articulated applies to the structural reform context, in which states often must pay substantial sums to comply with a federal court decree. It is important also to note that Publius believed that this was the case even before the passage of the Tenth Amendment. 
historical evidence indicates that the Federalists rejected the idea of broad equitable remedial powers in response to Anti-Federalist criticisms of the federal courts. This evidence lends additional support to the preceding textual and structural arguments made concerning the judicial power.

\section{B. The Original Understanding of the Judicial Power}

\section{The Methodology}

In the absence of any textual definitions of the judicial power, one must turn to understandings of the courts' power that are contemporaneous with the ratification. The evidence from the debates between the Federalists and the Anti-Federalists indicates that the Constitution was not understood to give the federal courts, via the judicial power, the authority they exercise today over state institutions. These debates serve as perhaps the most authoritative non-textual source for interpreting the Constitution, because they record the public explanation of the Constitution's meaning made by both sides in the ratification debates. In contrast, there was little recorded discussion during the Philadelphia Convention of the inclusion of equity in Article III, Section 2, and in any event these debates were unavailable to the public when they ratified the Constitution.

It would be incorrect to coinb these discussions for a few quotes that defend either side of the argument. Instead, one should approach the evidence as a dialogue in which Federalists advanced various justifications for constitutional provisions in response to specific AntiFederalist complaints. As the debates began both in the press and in the ratifying conventions soon after the close of the Philadelphia Convention, different arguments were raised, tested, and discarded. Out of this crucible emerged the justifications and explanations for the Constitution that won the day. These arguments not only indicate the "framers' intent," but they also provide evidence of what the framers, both Federalist and Anti-Federalist, believed the Constitution's terms meant at the time of ratification. Furthermore, the public explanation of the Constitution's meaning must bear controlling weight because it was that explanation that "sold" the Constitution to its ratifiers-the people.

\section{Early American Ambivalence Toward Equity}

Americans of the founding generation had a "love-hate" relationship with English and colonial equity jurisdiction. ${ }^{161}$ Legal complexity and the difficulties in transplanting English law to the frontier colonies

161. Two useful works canvass the history of equity during the Revolution and during the ratification of the Constitution. See HoFFer, supra note 46; MCDowELL, supra note 46. 
produced great confusion in American colonial courts. ${ }^{162}$ Equity provided a means for the colonists to adapt the English legal system to America. In defining equity, the colonists relied primarily upon William Blackstone's Commentaries on the Laws of England, which described the English courts of equity as carefully restrained by precedents and rules. According to Blackstone, equity was limited only to certain classes of cases, such as trusts, or to cases in which the common law did not provide a remedy, such as fraud cases. ${ }^{163}$ Blackstone also believed that a court's inherent powers allowed it to weigh equitable considerations in construing statutes, especially when the legislature had failed to anticipate the case presented. ${ }^{164}$

Even though they enjoyed the flexibility that equity brought to colonial law, the founding generation also feared the judicial discretion that gave equity its flexibility. Again, the colonists were influenced by Blackstone, who warned that without strict rules to bind equity courts, no limits would exist on the exercise of judicial power: judges' "powers would have becoine too arbitrary to have been endured in a country like this, which boasts of being governed in all respects by law and not by will."165 If federal judges were allowed to exercise equity powers, the revolutionaries feared, they would allow their decisions to be guided by their own preferences, rather than by the law. In a letter to a friend, Thomas Jefferson echoed these sentiments: "Relieve the judges from the rigour of text law, and permit them, with pretorian discretion, to wander into it's [sic] equity, and the whole legal system becoines incertain."166

American revolutionaries also distrusted equity because equity courts traditionally operated without juries. Ainericans associated equity courts with the Crown and its colonial administrators. ${ }^{167}$ English equity courts, after all, were merely an outgrowth of the King's powers,

162. Gordon S. Wood, The Creation of THE American Republic 1776-1787, at 298 (1969).

163. 3 William Blackstone, Commentaries on the Laws of ENGland *438-40 (1768).

164. John C. Yoo, Note, Marshall's Plan: The Early Supreme Court and Statutory Interpretation, 101 YALE L.J. 1607, 1610 (1992).

165. BLACKSTONE, supra note 163 , at $* 440$ (footnote omitted).

166. Letter from Thomas Jefferson to Philip Mazzei (Nov. 28, 1785), in 9 THE PAPERS of THOMAS JeFFerson 71 (Julian P. Boyd ed., 1954) (footnote omitted). Jefferson was echoing comments made as early as 1756; for example, in that year John Dickinson said of Pennsylvania:

[E]very court there is a court of equity, for both judges and juries think it hard to deny a man that relief which he can obtain nowhere else, and without reflecting that equity never intermeddles but where the law denies all manner of assistance, every judgment, every verdict is a confused mixture of private passions and popular error, and every court assumes the power of legislation.

MCDowelL, supra note 46, at 34 (footnote omitted) (emphasis in original).

167. Yoo, supra note 164 , at $1610-11$. 
and the Chancellor was one of the King's ministers. ${ }^{168}$ Consequently, Americans viewed the expansion of equity jurisdiction in the colonies as an effort to extend the Crown's control at the expense of local juries and local decisionmaking. In early American courts, juries decided questions of law as well as questions of fact, and were seen as the voice of the people in the judicial branch. ${ }^{169}$ Assigning a case to an equity court displaced the colonial jury and its lawfinding powers. Efforts to establish equity courts in the colonies thus amounted to, in the minds of the revolutionaries, veiled attempts to "undermin[e] the right to jury trial," 170 and, thus, to drive the people's representatives out of the courts.

\section{Judicial Review and Equity}

The founding generation discussed the relationship between the judicial power and equity during debate over what we today call the "political safeguards" of federalism. Concerned that the federal government would crush the states, the Anti-Federalists claimed that the states' representation in the Senate would provide little obstacle to the expansion of federal power. ${ }^{171}$ Foreshadowing current political rhetoric, the Anti-Federalists argued that Senators would become captured by an "inside-the-Beltway" mentality and would lose touch with their duty to protect states' rights. In response, the Federalists argued that the federal courts would serve as the ultimate check should Congress trample on the principle of federalism. ${ }^{172}$ It was in this context that Alexander Hamilton made his famous declaration in The Federalist No. 78 that the structure of the Constitution provided for judicial review: "The interpretation of the laws is the proper and peculiar province of the

168. Theodore F.T. Plucknett, A Concise History of the Common Law 191-98, 673-94 (5th ed. 1956).

169. IVIrliam E Nelson, Americanization of the Common Law 20-23 (1975); Akhil R. Amar, The Bill of Rights as a Constitution, 100 YALE L.J. 1131, 1182-99 (1991).

170. Joseph H. Smith \& Leo Hershkowitz, Courts of Equity in the Province of New York: The Cosby Controversy, 1732-1736, 16 Am. J. Legal Hist. 31 (1972); see also Shannon C. Stimson, THE AMERICAN REVolution IN the LAw 52-60 (1990).

171. See Saikrishna B. Prakash \& John C. Yoo, The Original Understanding of the Political Safeguards of Federalism, Paper presented to the Boalt Hall Conference on Federalism (Dec. 1995) (unpublished manuscript, on file with the California Law Review).

172. As James Wilson declared before the Pennsylvania Ratifying Convention:

[U]nder this constitution, the legislature may be restrained, and kept within its prescribed bounds, by the interposition of the judicial department. ... I had occasion, on a former day, to state that the power of the constitution was paramount to the power of the legislature, acting under that constitution. For it is possible that the legislature, when acting in that capacity, may transgress the bounds assigned to it, and an act may pass, in the usual mode, notwithstanding that transgression; but when it comes to be discussed before the judgeswhen they consider its principles, and find it to be incompatible with the superior power of the constitution, it is their duty to pronounce it void."

James Wilson, James Wilson Replies to Findley, Pennsylvania Ratifying Convention (Dec. 1, 1787), in I The Debate on the Constitution 822-23 (Bernard Bailyn ed., 1993) thereinafter Debate on THE CONSTITUTION]. 
courts. A constitution is in fact, and must be, regarded by the judges as a fundamental law. It therefore belongs to them to ascertain its meaning as well as the meaning of any particular act proceeding from the legislative body."173 Allowing Congress to be the final judge of the constitutionality of its enactments would allow Congress to place its authority before that of the people. Declared The Federalist No. 78, "[T]he constitution ought to be preferred to the statute, the intention of the people to the intention of their agents." 174

The Anti-Federalists agreed with this reading of the Constitution's text. According to Brutus, perhaps the most cogent Anti-Federalist thinker on judicial issues, "the courts are vested with the supreme and uncontrollable power, to determine, in all cases that come before them, what the constitution means; they cannot, therefore, execute a law, which, in their judgment, opposes the constitution, unless we can suppose they can make a superior law give way to an inferior."175 Given this shared understanding between the supporters and the opponents of the Constitution, the original understanding of the judicial power included the power of judicial review and of interpreting the laws.

Instead of addressing Anti-Federalist criticisms, this unfriendly agreement about judicial review only shifted the locus of the AntiFederalists' concerns from Congress to the Supreme Court. Rather than agreeing with the Federalists that the courts would prevent the federal government from violating states' rights, the Anti-Federalists believed that the federal courts would interpret the Constitution broadly and allow Congress to do as it pleased. In Anti-Federalist minds, the Court's equity power would allow the judiciary to assist Congress in expanding the powers of the federal government, and hence, the powers of the federal courts, over the states.

The Anti-Federalists' main concern was Article III, Section 2's grant of jurisdiction over federal questions cases "in Law and Equity," which the Anti-Federalists believed vested the Supreme Court with the power to engage in equity. Anti-Federalists believed that the equity courts would not be bound by the normal mles of interpretation when construing the breadth of the Constitution's grant of powers. Quoting Blackstone and Grotius, Brntus argued that " $[\mathrm{b}] \mathrm{y}$ this [the courts] are empowered, to explain the constitution according to the reasoning spirit of it, without being confined to the words or letter."176 "In their deci-

173. Federalist No. 78 , supra note 124 , at 525 .

174. Id.

175. Brutus XII, On the Power of the Supreme Court: Nothing Can Stand Before It, New York Journal, Feb. 7 \& 14, 1788, in 2 DeBATE on THE CONSTITUTJon, supra note 172, at 172.

176. Brutus XI, The Supreme Court: They Will Mould the Government Into Almost Any Shape They Please, New York Journal, Jan. 31, 1788, in 2 DeBATE on the ConstituTion, supra note 172, at $\mathrm{I} 31$. 
sions," he explained, "they will not confine themselves to any fixed or established rules, but will determine, according to what appears to them, the reason and spirit of the constitution." 177 Because the Constitution, in Brutus' opinion, used "general and indefinite terms," the courts would find it easy to expand the federal government's power beyond the intent of its frainers.

\section{Discretion or Jurisdiction?}

In addition to unlimited freedom to interpret the Constitution, AntiFederalists were also concerned that Article III's mention of equity would vest the federal courts with the unchecked discretion to use their unreviewable power in an unprincipled manner. As the Federal Farmer wrote:

It is a very dangerous thing to vest in the same judge power to decide on the law, and also general powers in equity; for if the law restrain him, he is only to step into his shoes of equity, and give what judgment his reason or opinion may dictate; we have no precedents in this country, as yet, to regulate the divisions in equity as in Great Britain; equity, therefore, in the supreme court for many years will be mere discretion. ${ }^{178}$

In other words, if a federal judge conld not reach his desired result under the law, equity would provide him a means for achieving his goal. Elsewhere, the Federal Farmer noted that by uniting law and equity jurisdiction in the Supreme Court, "we seem to mean to give the judge a discretionary power."179

The Anti-Federalist critique of the Court's equity power suggests a fear that it would be used, as it sometimes is now, in structural reform cases. Brutus warned, for example, that the federal equity power would lead to the "entire subversion of the legislative, executive and judicial powers of the individual states." 180 Although Brutus' concerns may have been exaggerated, they have been at least partly realized: in cases involving public institutions, the federal judiciary has usnrped states' control over their own budgets and programs.

Because the Anti-Federalists interpreted Article III, Section 2's mention of equity to grant the federal judiciary a broad equity power such as it exercises today, their reading is quite relevant to our inquiry into the original understanding of the equity power. If the Federalists

177. Id. at 132 .

178. Letters from The Federal Farmer No. 3 (Oct. 10, 1787), in 2 The Complete ANIIFederalist 234, 244 (Herbert J. Storing ed., 1981) [hereinafter Complete ANTI-Federalist].

179. Letters from The Federal Farmer No. 15 (Jan. 18, 1788), in 2 Complete ANTIFederalist, supra note 178 , at $315,322$.

180. Essays of Brutus No. 11 (Jan. 31,1788 ), in 2 CoMPLETE ANTI-Federalist, supra note 178, at 417,420 . 
agreed with the Anti-Federalists, one could reasonably conclude that Article III was understood to grant the courts an inherent equity power. A Federalist rejection of their interpretation, however, might indicate that the Constitution's proponents believed that Article III did not grant the federal courts the powers they exercise today.

In responding to Anti-Federalist criticisms, the Federalists apparently denied that the federal courts possessed inherent equity powers. When, in The Federalist No. 78, Publius predicted that the judiciary would be "of vast inportance in mitigating the severity, and confining the operation" of "unjust and partial laws," praising the utility of an inherent judicial equity power, but rather the benefits of the canons of statutory construction, which were "rules of common sense, adopted by the courts in the construction of the laws."182 Responding to Brutus' fears of a judicial power able to mold and expand the Constitution based on equitable principles, Publius declared: "[T] here is not a syllable in the plan under consideration, which directly empowers the national courts to construe the laws according to the spirit of the constitution."183

Nonetheless, the Federalists recognized that, even if the courts were not vested with equitable powers, giving thein equitable jurisdiction presented inherent dangers. The very nature of an equity court, Publius noted, the "great and primary use" of which "is to give relief in extraordinary cases, which are exceptions to general rules," threatened to unleash judicial discretion without limit. ${ }^{184}$ As Hamilton wrote in The Federalist No. 83: "To unite the jurisdiction of such cases with the ordinary jurisdictiou must have a teudency to unsettle the general rules and to subject every case that arises to a special determination."185 Seeking to avoid this danger, the Federalists concluded that the judicial power had to be restrained by precedents and rules. Declared The Federalist No. 78, "To avoid an arbitrary discretion in the courts, it is indispensable that they should be bound down by strict rules and precedents, which serve to define and point out their duty in every particular case that comes before thein." said of equity courts that "[i]t is true that the principles by which that relief is governed are now reduced to a regnlar system." 187

181. Federalist No. 78 , supra note 124 , at 528 .

182. The Federalist No. 83, at 559 (Alexander Hamilton) (Jacob E. Cooke ed., 1961) [hereinafter FEDERALIST No. 83]; see also Yoo, supra note 164, at 1612.

183. FeDERALIST No. 81, supra note 159 , at 543.

184. FEDERALIST No. 83, supra note 182 , at 569.

185. Id.

186. FEDERALIST No. 78, supra note 124 , at 529.

187. FEDERAList No. 83, supra note 182, at 569. 
No doubt Publius believed that many of the rules binding equity courts would be generated by precedent and by the courts themselves. But, as the Federal Farmer had argued, a new court would have precious few precedents to bind it in its early years. ${ }^{188}$ During the initial period, therefore, only Congress would be able to restrain the federal judicial power. To this end, the Federalists noted that, as a necessary component of its plenary authority to establish the inferior federal courts, Congress also would have the power to decide how those courts were to operate. "A power to constitute courts," Publius noted, "is a power to prescribe the mode of trial."189 Indeed, the first Federal Congress fulfilled this role when it passed the Judiciary Act of $1789,{ }^{190}$ and the Process Act of $1789,{ }^{191}$ which detailed the procedures to be used in cases in federal court.

Having established that congressional control would prevent the exercise of an unchecked judicial power, the Federalists then directly answered Anti-Federalist claims that Article III's mention of "all Cases, in Law and Equity" would give the federal courts an arbitrary discretion. Publius wrote in The Federalist No. 80:

It has also been asked, what need of the word "equity"? What equitable causes can grow out of the constitution and laws of the United States? There is hardly a subject of litigation between individuals, which inay not involve those ingredients of fraud, accident, trust or hardship, which would render the matter an object of equitable, rather than of legal jurisdiction, as the distinction is known and established in several of the states. It is the peculiar province, for instance, of a court of equity to relieve against what are called hard bargains: These are contracts, in which, though there may have been no direct fraud or deceit, sufficient to invalidate them in a court of law; yet there may have been some undue and unconscionable advantage taken of the necessities or misfortunes of one of the parties, which a court of equity would not tolerate. In such cases, where foreigners were concerned on either side, it would be impossible for the federal judicatories to do justice without an equitable, as well as a legal jurisdiction. Agreements to convey lands claimed uuder the grants of different states, may afford another example of the necessity of an equitable jurisdiction in the federal courts. This reasoning inay not be so palpable in those states where the formal and technical distinction between LAW and EQUITY is not

188. See supra note 178 and accompanying text.

189. Federalist No. 83, supra note 182 , at 559.

190. 1 Stat. 73 (1789).

191. I Stat. 93 (1789). 
maintained as in this state, where it is exemplified by every day's practice. ${ }^{192}$

Thus, Publius attempted to assuage Anti-Federalist fears by pointing to equity's traditional limitation to specific types of cases in which the common law had not provided a remedy. Equity was necessary to provide federal courts with jurisdiction in cases involving fraud or unconscionability, and cases involving federal law that raised equitable claims. Providing the federal courts with an equitable jurisdiction also guaranteed that when Congress created an equitable cause of action, a federal forum was empowered to hear it. Article III's mention of equity, Hamilton strenuously argued, was not a surreptitious attempt to grant the courts unchecked discretion. Publius' interpretation confirms our earlier conclusion, drawn from the text and structure of the Constitution, that "all Cases, in Law and Equity" was a grant of jurisdiction over certain types of cases, not a grant of inherent judicial power in those cases.

Federalists also appear to have believed that equity jurisdiction was necessary so that Congress could create causes of action that might be too difficult for juries to comprehend. Cases that are appropriate for equity courts, Publius noted, "are in many instances so nice and intricate, that they are incompatible with the genius of trials by jury."193 Litigation in chancery often required "a long train of minute and independent particulars" that would be difficult for a jury to follow, Publius believed. ${ }^{194}$ Equity cases also required "such long, deliberate and critical investigation as would be impractible [sic] to men called from their occupations and obliged to decide before they were permitted to return to them."195

A further Federalist defense of equity jurisdiction was grounded in equity's important role in ensuring that the federal courts maintained the uniformity of federal law and protected federal rights. As Publius wrote in The Federalist No. 82, the framers intended that every case arising under federal law would receive a hearing in federal court, in either original or appellate jurisdiction. ${ }^{196}$ Publius declared, "The evident aim of the plan of the convention is that all the causes of the specified classes [in Article III, Section 2], shall for weighty public reasons receive their original or final determination in the courts of the un-

192. The Federalist No. 80 , at 539-40 (Alexander Hamilton) (Jacob E. Cooke ed., 1961) [hereinafter FEDERALIST No. 80].

193. Federalist No. 83, supra note 182 , at 569.

194. Id.

195. Id.

196. The Federalist No. 82, at 555-56 (Alexander Hamilton) (Jacob E. Cooke ed., 1961) [hereinafter Federalist No. 82]. Professor Amar has reiterated this argument. Amar, supra note 137 , at 216-19. 
ion."197 The Constitution's drafters understood that federal claims could arise in state courts in either their law or equity jurisdictions. By extending "arising under" jurisdiction to cases in equity, the framers sought to ensure that federal claims would not be barred on appeal from a state court of equity. ${ }^{198}$ In this regard, the Constitution's mention of equity constituted a precaution to avoid future jurisdictional difficulties in the relationship between the federal and state courts.

This belief in the limited nature of the equity power was consistent with the framers' broader understanding of the judicial power, which was, in Publius' opinion, "beyond comparison the weakest of the three departments of power."199 This distribution of power resulted not only from the institutional powers of the Presidency and the Congress, but also from the inherent nature of an independent judiciary:

the judiciary, from the nature of its functions, will always be the least dangerous to the political rights of the constitution; because it will be least in a capacity to annoy or injure them. The executive not only dispenses the honors, but holds the sword of the community. The legislature not only commands the purse, but prescribes the rules by which the duties and rights of every citizen are to be regulated. The judiciary on the contrary has no influence over either the sword or the purse, no direction either of the strength or of the wealth of the society, and can take no active resolution whatever. It may truly be said to have neither Force nor Will, but merely judgment; and must ultimately depend upon the aid of the executive arm even for the efficacy of its judgments. ${ }^{200}$

Thus, Publius, the staunchest defender of the proposed Constitution, believed that the federal courts could exercise "merely judgment" and could not even execute their own decisions. The Federalist No. 78 further indicates that the judicial power was not understood to comprehend the power of the purse or the power to compel individuals to follow certain affirmative rules and regulations. It was the legislature which commanded the purse, not the courts, and it was the President which exercised the coercive power of society, not the judges. In reaching this conclusion, Publius relied not on any explicit provision of the Constitution, but rather on the generally accepted understanding of the function of independent conrts in a democratic society.

197. FEDERALisT No. 82, supra note 196, at 556.

198. Although the Supreme Court is currently the only federal court that may exercise appellate jurisdiction over state court decisions, the framers intended to allow Congress to vest such appellate jurisdiction in the lower federal courts, if it so chose. See id. at 556-57.

199. Federalist No. 78, supra note 124, at 523.

200. Id. at 522-23. 
A critic of this analysis might argue that this understanding was not widely shared immediately after the ratification of the Constitution. In particular, one might point to Chief Justice Marshall's comment in Marbury v. Madison" ${ }^{201}$ that "the individual who considers himself injured, has a right to resort to the laws of his country for a remedy."202 Thus, one could argue that in the very case that laid the foundations for judicial review, the Court also established the necessity of a judicial power to provide a remedy for every deprivation of a right. Indeed, one could read Marshall's comment on remedies as an interpretation of a fundamental aspect of the judicial power, just as was Marbury's holding on judicial review. This reading also could reflect the shared understanding of the judicial power that existed at the time of the Constitution's ratification.

Leaving aside the reliability of post-enactment legislative history, reliance upon Marbury to support the exercise of inherent remedial powers would be mistaken. If anything, Marbury supports the view that equitable remedial powers were not a part of the judicial power. Even though Madison had violated Marbury's right to his commission, the Court held that Marbury could receive no remedy. ${ }^{203}$ To be sure, Chief Justice Marshall framed the case as one of subject matter jurisdiction and judicial review rather than as one of remedies. ${ }^{204}$ The real fault of the congressional act in the case, however, was not a grant of unconstitutional original jurisdiction to the Supreme Court. The Judiciary Act's grant of a writ of mandamus was not truly a grant of subject matter jurisdiction, but instead was the definition of a remedy. ${ }^{205}$ It was Congress' grant of this remedy to the Court that Chief Justice Marshall held unconstitutional, because the writ of mandamus was not an appropriate remedy for the Court to exercise in Marbury's case.

If the Court possessed an inherent remedial authority, however, the unconstitutionality of Section 13 of the Judiciary Act should not have prevented the Court from reaching the merits of Marbury. Even without the power to issue a writ of mandamus, the Court could still have resorted to its equitable remedial power to order Madison to turn over Marbury's commission. An order for this type of specific performance by a government defendant would have been as close as an early nineteenth century court could have come to the equitable remedies that the courts impose today. But the Court did not do this, suggesting that the

201. 5 U.S. (1 Cranch) 137 (1803).

202. Id. at 166.

203. Id. at 180.

204. Id. at $176-80$.

205. Alchil R. Amar. Marbury, Section 13, and the Original Jurisdiction of the Supreme Court, 56 U. Chr. L. Rev. 443 (1989); William W. Van Alstyne, A Critical Guide to Marbury v. Madison, 1969 DUKE L.J. 36. 
early Supreme Court did not understand the "judicial Power" to grant the federal courts an inherent remedial power.

Hence, the available historical materials indicate that the proponents of the Constitution did not comprehend Article III to grant the wideranging remedial power that the federal courts exercise today. Instead, Article III's grant of equity jurisdiction was seen as just thatjurisdiction. While Anti-Federalists argued that Article III, Section 2 defined the judicial power, and that as a result the federal courts would exercise an unlimited equitable power, the Federalists disclaimed any such authority on the part of the judiciary. This explanation by the defenders and the eventual ratifiers of the Constitution should have dispositive weight in determining the extent of the judicial power, in no sinall part because it is consistent with conclusions drawn from the text and structure of the Constitution.

\section{The Equity Power's Historical Defense}

This examination of the origmal understanding of the judicial power suggests that federal courts have no textual or historical basis upon which to justify their use of equity powers against the states. The evidence itself belies the appeals to the "traditional attributes of equity power" made by the Supreme Court in Brown II. ${ }^{206}$ It seems clear that the framers did not understand the judicial power to encompass the imposition of affirmative obligations on the states; consequently, any subsequent expansions of the judicial power in this regard appear to be constitutionally illegitimate.

Efforts to provide a historical defense of the judicial equity power fall flat in light of this evidence. Brown II, for example, drew upon rather dubious support from the existing case law for its extraordinary assertion of equitable remedial power. In Brown II, the Court cited only two cases, Alexander v. Hillman ${ }^{207}$ and Hecht Co. v. Bowles, ${ }^{208} \mathrm{~m}$ defense of its sweeping assertion of federal equitable power, ${ }^{209}$ neither of which was on point. Alexander presented the question whether, under federal equity procedure, a federal court could hear a counterclaim in a proceeding concerning the distribution of the assets of a corporation placed in receivership. ${ }^{210}$ The only public law at issue was a jurisdictional statute. $^{211}$ Although it contained broad dicta about the nature of

206. Brown II, 349 U.S. 294, 300 (1955).

207. 296 U.S. 222 (1935).

208. 321 U.S. 321 (1944).

209. Brown II, 349 U.S. at 300 nn.4-5.

210. Alexander, 296 U.S. at 231.

211. Id. at $231,236$. 
equity, ${ }^{212}$ Justice Butler's opinion for the Court had nothing to do with constitutional rights, public institutional defendants, or remedies. ${ }^{213}$ Rather, Alexander was a purely private affair concerning equitable jurisdiction, not equitable remedies.

Hecht Co. was a suit by the federal government under the Emergency Price Control Act of 1942 to enjoin a Washington, D.C. department store from selling goods at prices higher than the authorized maximum price. ${ }^{214}$ Even though the Act stated that an injunction "shall be granted" upon a showing of a violation of the price controls, Justice Douglas held that a federal court could exercise equitable discretion in deciding whether to issue such an order. ${ }^{215}$ Denial of the injunction, therefore, was not necessarily erroneous, Justice Douglas concluded, because the department store immediately had ceased its pricing practices in good faith. ${ }^{216}$ As in Alexander, neither constitutional rights, public institutional defendants, nor affirmative remedies were at issue in Hecht. Hecht merely required the Court to interpret a statutory provision vesting it with the power to enjoin price control violations. That the Brown II Court relied on such tangential cases to justify an equitable remedial power indicates what a remarkable and unprecedented assertion of that power Brown II represented.

Academic efforts to provide a historical justification for the equity power are similarly unconvincing. In perhaps the most extensive effort to justify broad equitable remedies on textual, structural, and historical grounds, Professors Theodore Eisenberg and Stephen Yeazell claim that structural reform litigation is not unprecedented. ${ }^{217}$ Rather, they argue, it has characteristics in common with all litigation. ${ }^{218}$ According to these authors, critics of structural reform litigation "overlook the many detailed, coercive, and intrusive techniques that the legal system employs to deal with intransigent litigants before, during, and after traditional litigation." 219 These coercive procedures include exercising long-arm jurisdiction, compelling testimony, entering default judgments, utilizing preliminary remedies such as prejudgment attachment, and enforcing

212. Id. at 239 "Treating their established forms as flexible, courts of equity may suit proceedings and remedies to the circumstances of cases and formulate them appropriately to safeguard, conveniently to adjudge and promptly to enforce substantial rights of all the parties before them.").

213. Id. at $230-43$.

214. Hecht Co., 321 U.S. at 324.

215. Id. at $328-31$.

216. Id. at $326-31$.

217. Theodore Eisenberg \& Stephen $\mathrm{C}$. Yeazell, The Ordinary and the Extraordinary in Institutional Litigation, 93 HARv. L. Rev. 465 (1980).

218. Id. at 474.

219. Id. at 475 . 
judgments by attaching and converting a defendant's property. ${ }^{220}$ In these respects, Eisenberg and Yeazell claim, courts always have administered remedies after entry of a judgment, often in the face of intransigent defendants.

Eisenberg and Yeazell also argue that judicial supervision of "complex enterprises" is nothing new. ${ }^{221}$ Probate and trust law, one is told, often calls upon a court to administer property and supervise business enterprises, while bankruptcy law requires courts to supervise large, complex business and financial transactions. ${ }^{222}$ Administering a state institution pursuant to 42 U.S.C. $\S 1983$, which prohibits state officials from violating federal rights under color of state law, Eisenberg and Yeazell argue, does not significantly differ from monitoring the performance of executors and trustees. ${ }^{223}$ In each of these cases, courts use their equitable power to execute the statutory mandate of Congress. ${ }^{224}$

According to Eisenberg and Yeazell, neither the separation of powers nor federalism should stand in the way of judicial efforts to enforce the Constitution. Separation of powers concerns are adequately safeguarded in the institutional reform context by the various doctrines limiting courts' authority-case or controversy, standing, ripeness, mootuess, and political question-none of which applies to remedies once the merits have been adjudicated. ${ }^{225}$ Considerations of federalism, Eisenberg and Yeazell argue, cannot prevent the federal courts from intruding into state functions, where the operation of those functions have been performed in violation of the Constitution. ${ }^{226}$ Criticism of federal equitable remedies, in this view, really amounts to nothing more than criticism of the new substantive rights that courts have recognized, rather than the remedies used to vindicate them.

These misplaced arguments, however, overlook the unique impact of equitable remedies in the state institutional context. Beyond the mere difference in scope between overseeing a trust or a bankrupt business and, say, an urban school district, there exists a difference in kind between administering a private entity, on the one hand, and operating a multibillion dollar public institution year after year, on the other. The former often involves clear, defined ends for which there are often appropriate ineans readily available. For example, conserving the property of a trust may involve simply deciding to invest assets in treasury bills and taking other necessary steps to ensure the trust's preservation.

220. Id. at $475-81$.

221. Id. at 481 .

222. Id. at $482-86$.

223. Id. at $486-88$.

224. Id. at 494 .

225. Id. at $495-501$.

226. Id. at 501-06. 
Furthermore, if a court fails successfully to supervise a bankrupt business, then its assets can be sold off for the benefit of creditors and the remedy ends.

In contrast, institutional reform usually involves ambiguous goals and uncertain methods by which to achieve them. As Jenkins III ${ }^{227}$ demonstrates, a court often has little clue which measures will succeed in achieving its goals. Ưnlike judicial supervision of private businesses or trusts, there often may be no end in sight for institutional reform litigation. Failure of policies to achieve desired ends will not terminate the decree; instead, the court will continue to exercise jurisdiction and attempt new measures to reach its goal. Achieving a five percent return on the assets of a trust is one thing; achieving racial integration of a school district is a different matter altogether.

There is an even more fundamental difference between the private law disputes described by Eisenberg and Yeazell and structural reform litigation. In the former, the relevant parties agree to court supervision, and the court's orders do not displace the decisionmaking authority of competing, soinetimes coordinate, branches of government. Asserting jurisdiction over a trust or bankrupt enterprise does not eliminate the involvement of another entity that has been given authority over the trust by a popularly-enacted constitution or by a democratically-elected government, nor does it require widespread tax increases, or cutbacks in other government programs. Structural reform injunctions, however, oust the states' authority over their institutions, thus eliminating democratic control over some of their most basic functions, such as budgeting and resource allocation decisions. The structural injunction sidesteps majoritarian processes and denies the people their voice in the basic decisions of government.

Finally, Eisenberg and Yeazell ignore the basic separation of powers and federalism problems involved. Even if, as they argue, the federal courts are institutionally well-suited to implementing equitable remedies, that does not settle the matter because the courts' institutional capacity is not the issue. The critical inquiry should be whether the courts have the constitutional authority to impose the remedy at all; the question is not efficiency or effectiveness, but institutional authority.

The error of these scholars' approach becomes apparent if one imagines that, after deccades of supervising state institutions, the federal courts did in fact become effective at implementing broad, ongoing equitable remedies. Suppose further, that courts developed effective factfinding mechanisms and learned how to predict which remedies would work, how to communicate effectively their commands, and how to alter or even to reverse social trends through structural reform plans. Even

227. 115 S. Ct. 2038 (1995). 
with these hypothetical improvements im judicial abilities, I suggest that such judicial power would nonetheless be invalid for lack of constitutional authority. Just as Congress could not assume control over the prosecution of federal crimes, even if it proved to be a more effective prosecutor than the Justice Department, so too the federal courts cannot exceed their Article III limitations, even if they prove to use the power extraordinarily well. Just as the President cannot assume the judicial powers of a state and decide all cases therein, and Congress cannot assume executive power and seize operational command of a state's militia, so too the federal courts cannot assume state executive and legislative powers. Needless to say, such an illegitimate exercise of power is not saved by the fact that the authority of state rather than of federal officials is being displaced.

A supporter of structural remedies might respond to this evidence by arguing that the framers' early discussions concerned substance, not remedy. In other words, one could claim that the framing generation was concerned about equitable causes of action, rather than the remedial powers of the federal courts. To be sure, the judicial power was not originally understood to allow the federal courts to create equitable causes of actiou in all cases; such power would have overridden the overall limitations ou the powers of the federal judiciary and of the federal government. ${ }^{228}$

Further, it seems evident that the early concerns about the federal equity power went beyond substantive causes of action. Both causes of action and remedial powers were part of the same problem. If federal courts could create substantive causes of action directly under the Constitution, then the courts could use these causes of action as a springboard to justify the exercise of broad, intrusive remedial powers. After all, Blackstone had defined equity as necessary when the courts of law could provide no adequate remedy-in other words, equity was defined by its remedy. ${ }^{229}$

When the Federalists carefully argued that the equity power would extend only to "fraud, accident, trust, or hardship"230 they were placing limitations on both the substantive and remedial aspects of the equity power. Not only would the federal courts be limited to hearing equity cases in diversity under state law, but the courts' remedial powers would only be exercised in the context of those cases. A federal court would have the power, in diversity, to "relieve against what are called hard

228. Cf. United States v. Lopez, 115 S. Ct. 1624, 1634 (1995) (holding that regulating gun possession lay beyond Congress' enumerated powers).

229. 3 BLACKSTONE, supra note 163 , at $* 438-40$.

230. FEDERALIST No. 80, supra note 192 , at 539. 
bargains," as Hamilton put it, ${ }^{231}$ but it would not have the power to reorganize and manage public institutions. It would be a mistake for us today to assume that equity was originally conceptualized in the late eighteenth century as clearly differentiated into substantive and remedial powers.

The purpose of this Article has been to demonstrate that the text and structure of the Constitution do not create a federal equity power, and that there is no evidence that the Constitution was originally understood as vesting such a power in the judiciary. In the next Part, I propose an alternative approach to constitutional remedies.

\section{IV}

An Alternative Approach to the Judicial Power

This analysis has shown that the invocation of inherent judicial authority to impose equitable remedies upon state institutions is inconsistent with the text, structure, and original understanding of the Constitution. Critics of this conclusion may argue that if no inherent remedial authority can be found in the text, structure, or original understanding of the Constitution, such power is nonetheless required, lest constitutional violations be left without a remedy. This argument misperceives the nature of the separation of powers and the duties assigned to the different branches of government. The framers split up the powers of government not only to diffuse power and safeguard liberty, but also to create three different institutional competitors who would seek popular approval by maximizing the protection of constitutional rights.

Our political system has placed undue reliance upon the federal courts to enforce the Constitution, a duty they share with the President and Congress. Under the Constitution, the other two branches not only have the incentive, but also the obligation, to implement and effectuate remedies for constitutional violations. Absent clear congressional permission, federal courts can lay little legitimate claim to a power to impose structural injunctions upon the states. Despite this, the judiciary can continue to perform its law-declaring function in a structural reform suit by determining whether a constitutional violation has occurred. Once the violation is declared, however, the obligation to impose a remedy would fall upon the other entities in our national political system: the states, the executive branch, and the Congress. As this Article has argued, these branches possess functional advantages over the judiciary in formulating and implementing structural remedies.

231. Id. 
Assuming that the courts have interpreted and applied the Constitution correctly, the finding of a violation is federal law and as such is entitled to the same supremacy as are the "Constitution, and the Laws of the United States which shall be made in Pursuance thereof."232 Thus, under the Supremacy Clause state officials have a legal duty to execute the judiciary's decision. According to Article VI, "the Judges in every State shall be bound" by federal law. ${ }^{233}$ Further, "the Members of the several State Legislatures, and all executive and judicial Officers, both of the United States and of the several States," are required to take an oath "to support [the] Constitution."234 A duty to support the Constitution no doubt includes an obligation to enforce the decrees of the Supreme Court, if they have validly interpreted the Constitution. As Chief Justice Marshall declared, "If the legislatures of the several states may, at will, annul the judgments of the courts of the United States, and destroy the rights acquired under those judgments, the [C]onstitution itself becomes a solemn mockery."235

Although state officials are often the ones who violated the Constitution in the first place, remedies often can be implemented by other state governmental organs that were either unaware of the violations or that have experienced a change of heart. In particular, federal courts could abstain from ordering a remedy in favor of state courts which, as a state institution accountable to the community, could play the primary role in developing a solution. In any event, the Constitution designates state officials as the first line of defense for remedying constitutional violations by the states.

If state officials engage in widespread defiance of the Court, as occurred after Brown $I,{ }^{236}$ the obligation shifts to the other branches of the federal government to carry out the Constitution's dictates. Article $\Pi$, Section 3, for example, orders the President to "take Care that the Laws be faithfully executed."237 Recent scholarship has explored whether the President has the independent authority to interpret federal law in the course of executing the law or of vetoing legislation. ${ }^{238}$ If, as this scholarship argues, the President has the duty to veto unconstitutional legislation, and even the ability to refuse to enforce unconstitutional laws, he

232. U.S. CoNST. art. VI., cl. 2.

233. Id.

234. Id. cl. 3.

235. United States v. Peters, 9 U.S. (5 Cranch) 115, 136 (1809).

236. 347 U.S. 483 (1954).

237. U.S. CoNST. art. II., \& 3.

238. See, e.g., Frank H. Easterbrook, Presidential Review, 40 CASE W. REs. L. REv. 905 (198990); John Harrison, The Role of the Legislative and Executive Branches in Interpreting the Constitution, 73 CoRnell L. Rev. 371 (1988); Michael S. Paulsen, The Most Dangerous Branch: Executive Power to Say What the Law Is, 83 Geo. L.J. 217 (1994); Michael B. Rappaport, The President's Veto and the Constitution, 87 Nw. U. L. REv. 735 (1993). 
or she certainly also must have the independent obligation to enforce the Constitution, constitutional statutes, and judicial decisions properly interpreting those laws. ${ }^{239}$ Carried to its logical conclusion, this theory requires that the executive branch step in and correct unconstitutional conditions in state institutions even before a lawsuit has been filed. Where a federal court has already declared a constitutional violation, the President's task in this regard is even more compelling.

Congress has a parallel duty to vindicate the Constitution's commands and to guarantee the constitutional rights of the people. Like state officials, members of Congress must take the oath to support the Constitution, ${ }^{240}$ and they thereby assume the obligation to carry out its requirements. It is clear that Congress often exercises this independent power to interpret the Constitution in the course of deciding whether to pass legislation. ${ }^{241}$ To make these determinations, Congress often must interpret the Constitution independently of the Supreme Court, which cannot rule on the constitutionality of statutes until after Congress has passed them.

Congress' duty to interpret the Constitution should have force not only in deciding whether to adopt specific legislation, but also in identifying what types of legislation Congress ought to enact. To "support the Constitution," Congress has an obligation to pass statutes that protect constitutional rights, even (or perhaps especially) if it disagrees with Supreine Court decisions on the scope of those rights. For example, in the past, Congress has passed the Civil Rights Act of 1964 to implement the principles of the Equal Protection Clause, ${ }^{242}$ the Voting Rights Act to execute the Fifteenth Amendınent, ${ }^{243}$ the Civil Rights of Institutionalized Persons Act to eliminate unconstitutional prison conditions, ${ }^{244}$ and the Equal Access Act and the Religious Freedom Restoration Act to protect religious freedoin. ${ }^{245}$ Currently, Congress is considering a Property Rights Act to enforce the Takings Clause. ${ }^{246}$ By passing appropriate legislation, Congress can cure constitutional violations before they

239. Even if one does not believe that the President possesses any independent power to interpret the laws, it seems clear that the duty to execute the laws "faithfully" must include the enforcement not just of statutes, but also of the Constitution and of judicial decisions.

240. U.S. Const. art. VI, cl. 3.

241. See, e.g., Steven Ross, The Role of the Legislative and Executive Branches in Interpreting the Constitution, 73 CORNELL L REv. 383 (1988). During passage of the recent bill banning certain types of late-term abortions, for example, much of the debate in the Senate focused upon whether the bill was consistent with the Constitution and with the Supreme Court's decisions. See, e.g., 141 Cong. REc. S16,797-98 (daily ed. Nov. 8, 1995) (statement of Sen. Hatch).

242. 42 U.S.C. $\$ \$ 2000$ a to $2000 \mathrm{~h}-6$ (1994).

243. 42 U.S.C. $\$ \S 1971$ to $1973 \mathrm{bb}-4$ (1994).

244. 42 U.S.C. $\$ \S 1997$ to $1997-\mathrm{j}$ (1994).

245. Equal Access Act, 20 U.S.C. $\$ \S 4071-4074$ (1994); Rehigious Freedom Restoration Act, 42 U.S.C. $\$ \S 2000 \mathrm{bb}$ to $2000 \mathrm{bb}-4$ (1994).

246. Omnibus Property Rights Act of 1995, S. 605, 104th Cong., 1st Sess. (1995). 
occur, or it can make constitutional litigation unnecessary by providing clearer, more precise standards and procedures. If Congress has an obligation to prevent violations of the Constitution before they occur, there is no reason why Congress' responsibility should not extend to violations identified by the courts. Indeed, Congress' duty to cure constitutional violations would seem to be amplified following a judicial declaration that a state institution was not in compliance with the Constitution. ${ }^{247}$

A model of constitutional remedies that relies upon the initiative of the political branches, rather than upon judicial fiat, is likely to be more effective than the current practice of issuing structural injunctions. As I have argued, the text and the structure of the Constitution permitperhaps even compel-Congress, the President, or both to step in to remedy the injustice after courts declare a constitutional violation. Not only is this arrangement suggested by our constitutional structure, it is more sensible in terms of institutional competence than a system based upon the judicial implementation of structural remedies. Unlike the judiciary, the political branches possess the management and implementation skills and resources needed to engage in the structural reform of a state institution. Congress, for example, has at its disposal the federal treasury and the power of legislation, while the President can command the enormous federal bureaucracy. ${ }^{248}$

247. The argument presented here raises difficult questions conceming the scope of the powers that Congress can vest in the federal courts. Suppose that Congress chose explicitly to grant broad equitable powers to the judiciary over state institutions. Such a statute specifically could authorize the federal courts, upon a finding of a constitutional violation by a state institution, to take over the institution, to set spending and policy priorities, to make employment decisions, and so forth.

Under this Article's analysis, such a statute probably would be unconstitutional. As Marbury v. Madison, 5 U.S. (1 Cranch) 137 (1803), first recognized, Congress cannot extend the powers of the federal courts beyond those granted in Article III. Id. at 173-80. If the text, structure, and original understanding of Article III prohibit the federal judiciary from exercising remedial authority, then Congress cannot make such authority constitutional merely by approving.it.

It is possible that Congress has the power to transfer to the federal courts the authority to shape a whole body of substantive law, although 1 would agree with Justice Frankfurter's dissent in Textile Workers Union v. Lincoln Mills, 353 U.S. 448, 464-65 (1957) (Frankfurter, J., dissenting), that such a power would require the courts to engage in a non-judicial function forbidden by the Constitution. See, e.g., Bradford R. Clark, Federal Common Law: A Structural Reinterpretation, 144 U. PA. L REv. 1245, 1264-71 (1996). While this transfer of power might be a close call, it is an entirely different matter for Congress to vest the courts with a power that the text and structure of the Constitution seems to preclude, and which the framers and ratifiers believed was foreclosed to the judiciary. In any event, since Congress has not yet passed such a statute, we need not face this difficult question.

248. Furthermore, a remedy imposed by the political branches .would sidestep the problems created by sovereign immunity. As noted earlier, structural injunctions infringe on state sovereignty by interfering with a state's discretion over its own budgets and resources, and by ordering relief that borders on direct monetary compensation. See Jenkins III, 115 Ș: Ct. 2038, 2070 n.5 (1995) (Thomas, J., concurring); Edelman v. Jordan, 415 U.S. 651, 662-71 (1974); PAUL M. BATOR ET AL., Hart AND Wechsler's The Federal Courts AND the FEderal System 1191-92 (3d ed. 1988). Congress, however, may possess the authority to override directly state sovereign immunity under the 
Perhaps the greatest structural advantage of the remedial system proposed here is that it would permit democratically-accountable decisionmaking to govern constitutional remedies. One of the greatest faults of the current regime is that critical questions concerning spending, personnel, policy, and resource allocation are removed from the purview of democratically-elected or appointed officials. The unaccountable nature of the federal judicial power exacerbates the federalism and separation of powers difficulties described in this Article. Placing the primary responsibility on the President and the Congress to remedy constitutional violations would allow our national, democratically-elected institutions to make decisions on what measures to employ. Resource-allocation decisions could be made by officials who can take into account competing needs and limitations on resources. Their decisions on how to comply with the courts' decisions ultimately will be reviewable by the voters. Even if locally-elected authorities are displaced by the need to vindicate constitutional rights, at least the decisions will be made by national officials who are responsible and accountable to the national electorate.

Of course, one could criticize this proposal by arguing that Congress and the President simply might fail to enforce a judicial declaration, thereby leaving constitutional rights unvindicated. A case in which a judicial decision meets with such outright defiance should lead a federal court to question whether its decision has gone too far. The court should balance the correctness of its decision against the risk of losing its legitimacy by imposing a remedy in a fashion that not only lacks with popular approval, but also sparks affirmative, widespread opposition by the people's elected representatives.

In the event of such a deadlock with the political branches, the Court should still issue its declaration of a constitutional violation and leave the remedy to be implemented by another actor. The great triumph of Brown $I^{249}$ was not the immediate court-supervised remedies of Brown $I I,{ }^{250}$ which, as the Court later noted in Green v. County School Board, ${ }^{251}$ had failed to bring progress almost 15 years later. Rather, the

\footnotetext{
Eleventh Amendment at least in regard to ordering the state to remedy unconstitutional conditions; hence, its remedies would not suffer from the restrictions imposed upon judicial remedies by sovereign immunity. See Seminole Tribe v. Florida, 116 S. Ct. 1114, 1131-32 (1996) (sovereign immunity prohibits Congress from forcing states into federal court under the Commerce Clause); Atascadero State Hosp. v. Scanlon, 473 U.S. 234, 237-38 (1985) (discussing Congress' ability to act pursuant to Section 5 of the Fourteenth Amendment power to override sovereign immunity).

249. 347 U.S. 483 (1954).

250. 349 U.S. 294 (1955).

251. 391 U.S. 430, 437-38 (1968) (holding that "13 years after Brown II commanded the abolition of dual [public school] systems," a school district's "freedom-of-choice" plan for desegregating schools failed "to provide meaningful assurance of prompt and effective disestablishment of a dual system.").
} 
value of Brown I was its declaration of the principle of a color-blind Constitution, which was to be enforced by the President and Congress in a series of executive orders and far-reaching federal laws. It was the core of the judicial power-the power to declare the law-and not its remedial authority, that has had the most profound effect on the vindication of constitutional rights against the states.

Brown does not answer the difficult question that arises if the political branches were to oppose openly the decision of the Supreme Court. After Brown, President Eisenhower sent federal troops to execute judicial orders to desegregate southern universities, in the face of opposition by solne state officials. But history does not answer what would happen if the executive branch or Congress refused to implement a court's decision as happened, for example, in Worcester v. Georgia, ${ }^{252}$ when President Andrew Jackson refused to obey the Supreme Court's decision that an Indian tribe was entitled to its lands in Georgia. In that case, the Court's inability to impose an equitable remedy indeed may leave constitutional rights unvindicated.

\section{$\mathrm{V}$}

\section{CoNCLUSION}

It is more than likely that the Court will not adopt the model of constitutional remedies proposed here. Nonetheless, this Article can provide helpful advice for courts faced with the prospect of managing public institutions. Even if the courts can wield a remedial power in structural reform contexts, the "judicial Power of the United States" is not a blank check. Instead, the Supreme Court and the federal appellate courts should seek to impose strict rules and precedents to guide the district courts in their use of the equitable remedial power. If the federal judiciary neglects this responsibility, Congress can use its authority to establish and regulate the lower federal courts to restrain their remedial powers.

Imposing strict standards and constraints on judicial power in structural imjunction cases is consistent with the framers' understanding of equity and the federal courts. As it was understood during the lateeighteenth century, equity was an area of law that was "bound down by strict rules and precedents." ${ }^{2253}$ In exchange for the discretion to provide reinedies when none were available at law, the judge had to accept conditions and guidelines on its use. Justice Story's Commentaries on Equity Jurisprudence, perhaps the most authoritative early American treatise on equity, was not an extended theoretical musing on the

252. 31 U.S. (6 Pet.) 515 (1832).

253. Federalist No. 78 , supra note 124 , at 529. 
meaning of justice or on how to translate public values into reality. ${ }^{254}$ Rather, it was a technical handbook describing the different actions that could be brought in equity, the pleadings required, and the precise remedies allowed.

Current judicial doctrines concerning structural remedies do not take this understanding of equity seriously enough. As we have seen, the Supreme Court has been able to articulate only vague limitations upon the remedial authority of the lower courts. Judges are to "take into account" the interests of state and local governments, ${ }^{255}$ but they are not told how or to what extent they are to do so. Courts are told that "the nature of the violation determines the scope of the renedy," the Supreme Court has provided little explanation of this ambiguous phrase. In order to exercise their remedial powers in a manner that is consistent with the original understanding of equity, federal courts must develop clear rules to guide the development and implementation of a remedy.

Jenkins $I I I^{257}$ may have represented the first modest steps toward reaching this goal. In reversing elements of the district judge's extravagant plans, the Supreme Court resurrected the Milliken I principle that an intradistrict violation cannot justify an interdistrict remedy. In other words, if only one school district has infringed the constitutional rights of the plaintiffs, then only that school district and not others inust provide the remedy. This is a sensible restraint on judicial remedies, for it protects innocent governmental authorities-and ultimately innocent taxpayers-from footing the bill for constitutional violations they did not commit. However, this rule did not prevent the district judge in Jenkins from finding other inechanisms for extending a remedy's reach beyond the boundaries of a school district. For example, even though the court found no violation by outlying school districts, it still forced the State of Missouri to pay for a large share of the billion-dollar remedy. ${ }^{258}$ This had the effect of holding every taxpayer in the state financially responsible for the judge's remedy. Even though the Supreme Court held that the district judge had abused his authority by seeking to enhance the "desegregative attractiveness" of the Kansas City School District, it left intact his authority to prompt statewide tax increases. ${ }^{259}$

Jenkins III itself suggests that tighter standards are necessary to restrain judicial power. One obvious rule would prohibit federal courts

254. JoSEPh StORY, COMmENTARIES ON EQUiTY JURISPRUdenCE (1836).

255. Milliken II, 433 U.S. 267, 280-81 (1977).

256. Swann v. Charlotte-Mecklenburg Bd. of Educ., 402 U.S. 1, 16 (1971).

257. 115 S. Ct. 2038 (1995).

258. Id. at 2042-45.

259. This power was recognized in Jenkins II, 495 U.S. 33 (1990), and was not at issue in Jenkins III. 
from raising taxes. The federalism and the separation of powers difficulties with this tool have been discussed earlier. In raising taxes, federal courts have seized authority from the political branches and from the states, and they have threatened their own impartiality and independence. By allowing local governments to decide how much money is to be spent and how it is to be raised, courts will bolster the democratic process and restrain their use of extraordinary powers. Such a rule also is in keeping with the tradition of equitable remedies in the federal courts, for not until the Jenkins II case in 1990 had the Court ever approved a judicially-imposed tax increase. ${ }^{260}$

Prohibiting judicial taxation is only one aspect of a larger problem with judicial remedies of which federal courts should beware. Courts should refrain from enforcing remedies that bring in third parties, either in the giving, receiving, or administering of a remedy. The remedy in Jenkins III provides a useful example of multiple violations of this principle. First, the district judge mitially ordered the state to pay seventyfive percent of the costs of the remedy, which forced taxpayers outside of the guilty school district to pay for the remedy. ${ }^{261}$ Second, the district judge ordered programs and construction that benefited all students in the Kansas City school district, instead of only those students directly harmed by segregation. As Justice Thoinas put it, "the court cannot order broad remedies that indiscriminately benefit a school district as a whole, rather than the individual students who suffered from discrimination." "262 Third, the district court relied on a number of intervenors, special committees, experts, and special masters to help develop its remedies. ${ }^{263}$ These advisers and interested groups transformed the judicial process into a forum for the allocation of resources and the development of programs. There is different place where this process is supposed to occur: the legislature.

To prevent overbroad remedies, the Supreme Court should declare that structural injunctions be narrowly tailored to cure the constitutional violation. One clear application of this standard would be to require that those who receive the remedy should be those who have been harmed by the state. This is a standard that would place equitable remedies on the same footing as other race-based remedies, which must survive the strict scrutiny standard enunciated by the Court in Richmond

260. Of course, a lack of finances cannot justify a constitutional violation. My point here is not that courts should keep in mind fiscal constraints when designing their remedies. Instead, the argnment is that there are eertain avenues that courts can use to remedy constitutional violations, and that the separation of powers precludes courts from pursuing some of these avenues.

261. Jenkins $I I, 495$ U.S. at 41 .

262. Jenkins $I I, 115$ S. Ct. at 2073 (Thomas, J., concurring).

263. Id. at 2072 n.6 (noting creation of "desegregation monitoring committee"). 
v. J.A. Croson Co. ${ }^{264}$ and in Adarand Constructors, Inc. v. Pena. ${ }^{265}$ As the Court said in Adarand, to survive constitutional review, race-based remedies must be narrowly tailored to advance a compelling government interest. ${ }^{266}$ It makes little sense for the federal courts-an arm of the federal governinent-to be free to engage in race-based discrimination when the President, Congress, and the states cannot. Furthermore, requiring structural remedies to ineet such standards will help reduce judicial discretion by bringing to the area the rules developed in other race cases.

A requirement that the remedy be narrowly tailored does not mean that courts must issue detailed orders. Indeed, a court's respect for the limitations on its own powers and for the rights of other governinent authorities should encourage less specific remedies. To use Jenkins III as an example, it is difficult to trace a direct relationship between the aesthetic appearance of the magnet schools or the types of classrooms to be built, and curing a constitutional violation. There can be little doubt that pretty schools or well-designed classrooms are desirable, but often it is difficult to show how these reforms will directly cure a constitutional violation. Further, as others have argned elsewhere, the implementation of extremely detailed orders requires continual judicial supervision, which forces courts to supplant the executive branch's management of an institution's day-to-day operations. ${ }^{267}$

Courts instead could achieve narrow tailoring by setting out objectives that are directly related to the constitutional harm. If students have suffered segregation, then courts might issue orders requiring the end of de jure discrimination on the basis of race and the implementation of a race-neutral school assigninent plan. The precise particulars concerning the end of segregation and the implementation of a plan would be left to the political branches or to the local government. In order to ensure good faith compliance, the courts could review periodically the progress of the remedy toward curing the violation. As with the earlier discussion of taxation and funding, such a rule of equitable remedies would preserve much of the decisionmaking authority that is reserved for the democratically-elected and accouutable branches.

Due to the judiciary's past failures to place meaningful restraints on its own remedial powers, Congress has attempted to rein in judicial remedial powers in the manner suggested by this Article. In the spring of 1996, Congress passed as part of a budget bill the "Prison Litigation

264. 488 U.S. 469, 493-94 (1989) (O'Connor, J.) (plurality opinion).

265. 115 S. Ct. 2097, 2112 (1995).

266. Id.

267. Frug, supra note 118 , at 789. 
Reform Act of 1995."268 Limited to federal judicial remedies over prisons, the Act places strict substantive limits on the manner of relief that courts can order in prison condition lawsuits. When prospective relief is sought, for example, only remedies that meet a three part-test can be ordered: the remedy must be "narrowly drawn," it must "extend[] no further than necessary to correct the violation of the Federal right," and it must be "the least intrusive means necessary to correct the violation of the Federal right."269 These standards not only will require the lower courts to consider more carefully the remedies that they plan to impose, they also readily lend themselves to de novo review by the appellate courts. Constitutional remedies no longer will be invariably fact-bound determinations solely within the purview of the trial judge.

In addition to these new substantive standards, the Act contains procedural innovations designed to restram the federal courts. For example, it places tough hurdles in the way of courts that intend to adopt certain types of remedies. Courts are prohibited from using prisoner release orders except as a last resort, and the Act requires that any such orders be issued by a three-judge court. ${ }^{270}$ The Act also restricts the use of special masters, limits their compensation, and restricts their powers. ${ }^{271}$ New parties, such as prosecutors, are given standing to challenge the remedy, and courts must rule immediately on any motion to modify or terminate prospective relief. ${ }^{272}$

In this manner, the Prison Litigation Reform Act will provide the federal courts with rules to guide the exercise of their equitable remedial powers. Although the Act constitutes an extraordinary step on the part of Congress, it also reflects growing frustration with the courts' inability to control their own remedial discretion in a principled manner. It seems likely that further legislation in this vein may follow in other areas, such as judicial taxation. ${ }^{273}$

A critic might argue that Congress has no authority to interfere further with the courts' remedial powers, but this position ignores Congress' plenary powers over the federal courts. Congress possesses the power to establish and regulate the lower courts, ${ }^{274}$ which gives it the discretion to determine the structure and powers of Article III tribunals. Congress also has the authority to determine the jurisdiction of the

268. Pub. L. No. 104-134, Title VIII (1996). The author served as General Counsel of the Senate Judiciary Committee when this legislation was passed.

269. Id. § 802(a) (amending 18 U.S.C. § 3626(a) (1994)).

270. Id.

271. Id. (amending 18 U.S.C. $\$ 3626(\mathrm{f})$ ).

272. Id. (amending 18 U.S.C. \& 3626(a)).

273. See, e.g., S. 1817, 104th Cong., 2d Sess. (1996) (placing procedural restrictions on federal courts' ability to impose taxes).

274. U.S. ConST. art. I, §8; id. at art. III, § 1 . 
federal courts and the authority to define federal causes of action, which implies that Congress also has the sole right to decide how those causes of action will be enforced.

Instead of being feared, congressional involvement in constitutional remedies should be welcomed. Congress can marshal far greater resources than the courts to curing constitutional violations. Congress also can balance what is desirable against what is possible; the legislature is far more capable of determining how much can be accomplished and what resources are available. Congress can not only articulate standards to guide remedial efforts, but also experiment with new techniques and plans to address constitutional harms.

As we enter the next century, structural reform cases are likely to become the subject of a more interactive process, in which Congress and the judiciary react and learn from each other. Just as this Article went to press, for example, the Supreme Court articulated new principles to guide lower courts in the use of structural injnnction in the prison context. ${ }^{275}$ Although the Court did not rely upon the new Prison Litigation Reform Act, its decision in Lewis $v$. Casey advanced the same objectives of restricting judicial discretion and of deferring to democraticallyaccountable prison authorities.

In Lewis, the Court reversed a lower court's decree that reqnired Arizona prison authorities to provide a full-service law library for prisoners complete with law librarians and multilingual legal assistants. ${ }^{276}$ First, the Court criticized the lower court for failing to defer to prison authorities in deciding how to guard maximum-security prisoners. ${ }^{277}$ Second, the Court found that the excessive detail of the district court's order improperly had "enineshed" the judiciary in the minutiae of prison operations. ${ }^{278}$ Third, the Court criticized the district judge for failing to provide state authorities with an ample opportunity to participate in the development of the remedy. As Justice Scalia wrote for an eight-Justice majority: "[T]he order was developed through a process that failed to give adequate consideration to the views of state prison authorities."279

In reversing the remedial decree in Casey, the Court showed that it is becoming coguizant of the inherent limitations of its remedial powers. Discussing the goal of a constitutional remedy, for example, the Court began to delineate the limitations imposed on the judiciary by the separation of powers. While acknowledging that the judiciary must

275. Lewis v. Casey, 1996 U.S. LEXIS 4220 (U.S. June 24, 1996).

276. Id. at *34

277. Id. at *30-31.

278. Id. at *32 (quoting Bell v. Wolfish, 441 U.S. 520, 562 (1979)).

279. Id. at $* 32$. 
provide a remedy for past harms, the Court also declared that "it is not the role of courts, but that of the political branches, to shape the institutions of government in such fashion as to comply with the laws and the Constitution."280 In other words, the Court has begun to draw a line between reversing past injuries, which apparently fall within the federal remedial power, and curing prospective violations, which apparently is up to the political branches. In Justice Scalia's words: "It is for the courts to remedy past or imminent official interference with [plaintiffs' rights]; it is for the political branches of the State and Federal Governments to manage prisons in such fashion that official interference with [plaintiffs' rights] will not occur."281 This conclusion is consistent with the vision of constitutional remedies outlined in this Article.

In a second development, the Court appeared for the first time to suggest that federalism concerns alone can provide the grounds to invalidate a remedy. In criticiziug the failure of the district judge to consult properly with the state on the remedy, the Supreme Court curtly declared: "This will not do." 282 The Court reiterated that states should be given "the first opportunity" to correct the constitutional violation before the imposition of structural injunctions. ${ }^{283}$ Unless states are given the chance to participate early and often in the reinedial process, the Court concluded, a remedy will be reversed. Justice Scalia wrote: "The State was entitled to far more than an opportunity for rebuttal, and on that ground alone this order would have to be set aside."284

Thus, it seems that the story of structural injunctions and of racebased remedies may be entering a new phase. Both the Congress and the Suprene Court appear to be making the initial steps toward a model of constitutional remedies similar to the one suggested by this Article. This is a nodel that requires the federal courts to pay fuller deference to the political branches, and permits federalism and the separation of powers to play a larger role in the shaping of remedies. It also appears that the future will bring forth more interaction between the different branches and levels of government in the task of curing constitutional violations. As Congress becomes more involved, structural remedies in the future will be less the product of judicial fiat and more the result of cooperation between the branches. In the long run, this may lead to the more effective protection of constitutional rights.

280. Id. at *11.

281. Id.

282. Id. at *34.

283. Id. at *32 (quoting Preiser v. Rodriguez, 411 U.S. 475, 492 (1973)).

284. Id. at *34. 
